\title{
The role of water in catalytic biomass-based technologies to produce chemicals and fuels
}

\author{
László T. Mika ${ }^{\mathrm{a}, \mathrm{b}}$, Edit Cséfalvay ${ }^{\mathrm{a}, \mathrm{b}}$, István T. Horváth ${ }^{\mathrm{b}, *}$ \\ a Department of Chemical and Environmental Process Engineering, Budapest University of Technology and Economics, Budafoki str. 8, H-1111 Budapest, \\ Hungary \\ ${ }^{\mathrm{b}}$ Department of Biology and Chemistry, City University of Hong Kong, Tat Chee Avenue 83, Kowloon, Hong Kong
}

\section{A R T I C L E I N F O}

\section{Article history:}

Available online 4 January 2015

\section{Keywords:}

Water

Biomass

Hydrolysis

Hydration

Dehydration

Deoxydehydration

\begin{abstract}
A B S T R A C T
Water can have many different roles in catalytic biomass-based technologies to produce chemicals and fuels. Since water is one of the two basic chemicals of nature used during photosynthesis, biomass contains different amount of water, which can be advantageously utilized during the conversion schemes. Water could be the solvent of the reactions or just either the eliminated product or the reactant resulting in hydration and hydrolysis. Since some of these roles are intrinsically part of the natural system, their change could be very difficult or not even possible. Therefore, the designer of the chemistry or the process must understand the possible roles of water at both the molecular and the macroscopic levels.
\end{abstract}

(c) 2014 Elsevier B.V. All rights reserved.

\section{Introduction}

Water is one of the most abundant molecules on Earth which has its own global cycle [1]. It plays many important roles by providing a very stable and mostly neutral medium for life [2], serving as solvents for many different reactions, and participating in a large number of chemical transformations [3,4]. The water cycle involves a continuous global distillation process resulting in two distinct aqueous environments having higher and lower level of dissolved salts $-96.5 \%$ salted water and $2.6 \%$ fresh water. While the salted water in the oceans and seas contains dissolved sodium chloride and some other salts that make it useless for human consumption, fresh water in our rivers and lakes generally contains much less salts and other solutes. Consequently, evolution has adjusted the chemistry of the living habitats of the two different aqueous environments [5]. Unfortunately, human activities have increased the levels of dissolved man-made contaminants, including inorganic and organic chemicals and materials, which could have very negative health and environment effects. The societal acceptance of the potential negative impacts of "dirty water" [6] and the recognition of the important role of pollution prevention or "green chemistry" [7], we are discharging less and less contaminated water to the environment because of the increased use of cleaner technologies

\footnotetext{
* Corresponding author. Tel.: +852 3442 7402; fax: +852 34420522.

E-mail address: istvan.t.horvath@cityu.edu.hk (I.T. Horváth).
}

as well as closed waste water systems combined with state-of-the art waste water treatment technologies.

Although the complete depletion of coal, crude oil, and natural gas will probably take several centuries if not millennia, we should produce more and more carbon-based chemicals from biomass to slow the depletion of the fossil resources and use carbon neutral consumer products [8]. Interestingly, the largest component of biomass is water, which could be as little as few percent in an old tree, but as high as $80 \%$ of corn kernel or living cells [9]. If our drive to use biomass-based technologies for the production of all carbonbased consumer products will be successful, the volume of water from converted biomass could be large enough to consider it for the production of drinking water. Because of the aqueous nature of biomass, most of the molecules involved are highly functional and many have oxygen-containing functional groups. This can be simply demonstrated by carbon, hydrogen, oxygen, and nitrogen content of the dry matter of biomass and younger components of fossil resources (Table 1).

Conventional productions of carbon-based chemicals and fuels are based on the separation of saturated and aromatic hydrocarbon constituents of fossil resources followed by the introduction of oxygen, nitrogen, and sulfur containing functional groups. In contrary, most of the components of biomass are multifunctional and their conversion to chemicals and fuels require selective defunctionalization. One of the key strategies of the development of successful biomass-based chemical and fuel industry is how to match the properties of the components of biomass with proper 
Table 1

Elemental composition of materials on dry weight basis.

\begin{tabular}{|c|c|c|c|c|c|c|}
\hline & Carbon (wt\%) & Hydrogen (wt\%) & Oxygen (wt\%) & Nitrogen (wt\%) & Sulfur (wt\%) & Ref. \\
\hline Miscanthus fresh & $47.3-47.6$ & $5.77-5.95$ & $42.1-43.5$ & $0.33-0.45$ & $0.05-0.08$ & {$[10,11]$} \\
\hline Switchgrass & $43.5-47.5$ & $5.75-6.18$ & $37.57-44.82$ & $0.36-0.77$ & $0.04-0.19$ & {$[12,13]$} \\
\hline Sorghum stalk & $40.0-46.1$ & $5.20-5.76$ & $40.63-40.70$ & $0.39-1.40$ & $0.20-0.27$ & {$[14,15]$} \\
\hline Sugar cane bagasse & 48.6 & 5.87 & 42.85 & 0.16 & 0.04 & [12] \\
\hline Wheat straw & $42.9-47.6$ & $5.11-5.8$ & $40.39-42.41$ & $0.43-0.73$ & $0.09-0.29$ & {$[16,17]$} \\
\hline Straw (average) & $45-47$ & $5.8-6.0$ & $40-46$ & $0.4-0.6$ & $0.05-0.2$ & [18] \\
\hline Corn stover & 42.60 & 5.06 & 36.52 & 0.83 & 0.09 & [18] \\
\hline Bark & $48-52$ & $5.7-6.8$ & $24.3-40.2$ & $0.3-0.8$ & $<0.05$ & [18] \\
\hline Forest residues & $48-52$ & $6.0-6.2$ & $40-44$ & $0.3-0.5$ & $<0.05$ & [18] \\
\hline Wood without bark & $48-52$ & $6.2-6.4$ & $38-42$ & $0.1-0.5$ & $<0.05$ & [18] \\
\hline Peat & $52-56$ & $5.0-6.5$ & $30-40$ & $1-3$ & $0.05-0.3$ & [18] \\
\hline Black coal & $76-87$ & $3.5-5.0$ & $2.8-11.3$ & $0.8-1.5$ & $0.5-3.1$ & [18] \\
\hline Lignite (North-Dakota) & 31.80 & 4.51 & 26.35 & 0.59 & 0.84 & [18] \\
\hline Bitumenous coal (Pennsylvania coal) & $83-89$ & $4-6$ & $3-8$ & $1.4-1.6$ & $1.4-1.7$ & [18] \\
\hline Anthracite (Pennsylvania coal) & $91-94$ & $2-4$ & $2-5$ & $0.6-1.2$ & $0.6-1.2$ & [18] \\
\hline
\end{tabular}

conversion technologies to produce the products with minimal structural changes and by energy efficient methods. For example, it seems counter intuitive to use vegetable oils for the production of a highly functionalized product and vice versa use carbohydrates for the production of alkanes.

\section{Discussion}

The production of biomass-based chemicals and fuels should consider the relationships of the chemical composition of the feedstocks and the product(s) including the molecular structure of their constituents. Water is an intrinsic part of biomass, which could be as little as few percent in an old tree, but as high as $80 \%$ in plants (Table 2) and living cells. Therefore, the overall efficiency of the conversion of biomass is highly dependent on how well can be matched its water content with the conversion technology, as the removal of excess water could be extremely energy demanding. In this chapter, we provide a short summary of the water content of various biomass resources; the pre-treatment processes involving water followed by the review of conversion opportunities using water as a solvent and/or as a reagent.

\subsection{Water contents of various biomass resources}

In general, grains with moisture contents from 12 to $22 \mathrm{wt} \%$ (based on wet weight) are mature enough to be harvested and dry enough for storage. While switch grasses and Miscanthus usually have lower, the stalk of sugarcane and sweet sorghum have significantly higher water content than grains. Stalks have 67-72 wt\% water, which is frequently squeezed to form a "raw juice" resulting in an easily accessible sugar rich aqueous raw material.

With the exception of direct energy generation, the utilization of biomass often requires physical and/or chemical pre-treatment in order to modify advantageously the physical and/or chemical structures of the components. The most frequently used process is the hydrolysis, which converts polysaccharides to mono- and disaccharides. For the enzymatic conversion of the latter to ethanol [30,31], butanol and acetone [32], and lactic acid [33], higher moisture content could be an advantage since the enzymatic reactions are performed in aqueous environments.

Biomass wastes are generally classified into three main groups: forestry residues, agricultural residues, and food wastes (Table 3). Forestry residues are commonly divided into primary and secondary residues. Primary residues accruing from cultivation and secondary residues are produced by the wood processing industry. Although forest product industries could generate the same residues and they could have been used as raw materials, they are beyond the scope of this review.
While forestry residues are usually combusted in power generation plants, high water content of the biomass could have negative effects on the overall energy output [34]. Pre-drying of forestry residues can decrease the water content to the typical value of $8-10 \mathrm{wt} \%$ leading to better combustion properties. Alternatively, forestry residues with high moisture levels can be burned with coal [35].

Considering other types of utilizations such as extraction of cellulose and its conversion to sugar via hydrolysis [30], and anaerobic digestion to biogas [57], the water content is a required component in these technologies.

Agricultural residues are produced and collected at land fields. By far, the largest source of crop residues is the straw and stover from grain crops representing a wide range of moisture content. Those having higher moisture content are suitable for forage or fermentation. While dry biomass, such as straws, can be utilized via gasification or combustion to produce energy, wet biomass has been used for chemical transformations or fermentation to produce chemicals. Biomass with even high water and nutrient content is usually used for forage.

Animal excrements, manure and slurry can be considered as a significant part of agricultural residues [53]. Among the various livestocks, the largest population include swine, cattle and poultry, which generate an enormous volume of slurry and manure, for example, China's manure production was 1900 million tons in 2010 [58]. The water content of slurry can be as high as $99.5 \mathrm{wt} \%$ so it is used for land applications in crop fields. (Table 4) [59]. Due to its nutrient content, solid manure can be dispersed on crop fields as fertilizer, however, its volume is influenced by physical, chemical and biological properties of the soil as well as local environmental standards [60]. Although surplus manure was treated as waste in the 1990s [60], its valorization has become an issue in the last two decades.

Additional treatment and utilization technologies are based on composition analysis (Table 5) including composting [63], anaerobic digestion, and co-composting with municipal wastes [64]. Since dairy cattle manure contains the highest level of lignocellulose, its hydrolysis to monosaccharides [65] is a possible form of utilization.

Food wastes can be produced before and during the preparation of meals as well as discarded in the manufacturing/production, distribution, wholesale/retail and food service sectors including restaurants, schools and hospitals. Food wastes consist of a broad range of chemicals and materials and moisture content could be as high as $70-80 \%$.

While composting has become less important in the last two decades due to the large area requirements and VOC formation, the anaerobic digestion has gained increased attention as a better processing alternative for food waste aiming to produce biogas 
Table 2

Moisture contents of biomass resources.

\begin{tabular}{|c|c|c|c|}
\hline Biomass & Types & Moisture (wt\%) & References \\
\hline \multirow[t]{4}{*}{ Corn } & Grain at harvest time & $20-22$ & [19] \\
\hline & Grain as the market standard & 15.5 & {$[20]$} \\
\hline & Clean grain stored with aeration & $13-15$ & [21] \\
\hline & Shelled grain & 15.5 & {$[22]$} \\
\hline \multirow[t]{3}{*}{ Barley } & Clean grain stored with aeration & $12-14$ & [21] \\
\hline & Mature grain on the plant & $30-50$ & [23] \\
\hline & Grain at harvest time & $12.5-18$ & {$[23]$} \\
\hline \multirow[t]{2}{*}{ Miscanthus } & Sinensis Gracillimus type & 12.51 & {$[10]$} \\
\hline & Silberfeder type & 14.54 & [10] \\
\hline Oats & Clean grain stored with aeration & $12-14$ & {$[21]$} \\
\hline Rye & Clean grain stored with aeration & $12-13$ & [21] \\
\hline \multirow[t]{3}{*}{ Sorghum } & Clean grain stored with aeration & $13-13.5$ & [21] \\
\hline & Stalk harvested in November in Greece & 67.20 & {$[24]$} \\
\hline & Stalk of sweet sorghum & 70 & [25] \\
\hline \multirow[t]{2}{*}{ Soybean } & Clean grain storage with aeration & $11-13$ & [21] \\
\hline & Shelled grain & 13 & [22] \\
\hline \multirow[t]{2}{*}{ Sugar cane } & Stalk (average) & 75 & [26] \\
\hline & Top of the stalk & 82.3 & [27] \\
\hline \multirow[t]{2}{*}{ Sunflower } & Clean grain stored with aeration & 8-11 & [21] \\
\hline & Mature grain & $\sim 50$ & [28] \\
\hline \multirow[t]{2}{*}{ Switch grass } & Dakota leaf type & 9.84 & [29] \\
\hline & Columbus leaf type & 13.27 & [29] \\
\hline \multirow[t]{2}{*}{ Wheat } & Clean grain stored with aeration & $13-14$ & [21] \\
\hline & Shelled grain & 14 & {$[22]$} \\
\hline
\end{tabular}

and fertilizer [66,67]. While the efficiency of anaerobic digestions is dependent of the water content in the feedstock, higher initial organic contents will lead to higher biogas production, as expected [68].

\subsection{Water requirement for biomass processing}

The availability of fresh water greatly determines the sustainability of the production of biomass. While the drought resistance properties of plants are one of crucial parameters during plant selection, the water requirements for processing represent another important issue [69]. Depending on the climate, the usual rainfall can cover the main portions of the water requirements, but irrigation become crucial in dry seasons to maintain high yield and good quality. In general, various pre-treatment methods involving water have been practiced for most of the processing technologies including saccharification either with acids or bases, esterification, hydration/dehydration, and deoxydehydration.

Steaming with or without explosion can be performed mainly independently of the biomass' initial water content, therefore it is

Table 3

Water content of forestry and agricultural residues and food wastes.

\begin{tabular}{|c|c|c|c|}
\hline Biomass wastes & Type & Moisture content (wt\%) & Ref. \\
\hline $\begin{array}{l}\text { Forestry } \\
\text { residues }\end{array}$ & $\begin{array}{l}\text { Fresh } \\
\text { Dry } \\
\text { Bark } \\
\text { Coniferous tree with needles } \\
\text { Christmas tree in USA } \\
\text { Fresh wood chips and sawdust } \\
\text { Dry wood chips and sawdust } \\
\text { Fresh wood chips } \\
\text { Wood chips stored and air-dried } \\
\text { Waste wood } \\
\text { Yard waste, mostly wood chips }\end{array}$ & $\begin{array}{c}48.91 \\
8-10 \\
45-65 \\
50-60 \\
37.81 \\
40-60 \\
10-20 \\
40-60 \\
30-40 \\
10-30 \\
38.07\end{array}$ & $\begin{array}{l}{[10]} \\
{[10]} \\
{[35]} \\
{[35]} \\
{[9]} \\
{[36]} \\
{[36]} \\
{[36]} \\
{[36]} \\
{[36]} \\
{[37]}\end{array}$ \\
\hline $\begin{array}{l}\text { Agricultural } \\
\text { residues }\end{array}$ & $\begin{array}{l}\text { Corn leaf } \\
\text { Corn stover } \\
\text { Corn stalk } \\
\text { Barley straw after harvesting, Canada } \\
\text { Rape stalk, Finland } \\
\text { Rice hulls } \\
\text { Rice straw, Canada } \\
\text { Rice straw } \\
\text { Post-hydrolysis lignocellulose } \\
\text { Sorghum bark, Greece } \\
\text { Sorghum pith, Greece } \\
\text { Sunflower stalks sundried after harvesting in India } \\
\text { For forage and fermentation } \\
\text { Wheat straw for gasification or energy } \\
\text { Wheat straw as pellets } \\
\text { Mixed waste paper } \\
\text { Sugar cane bagasse, Hawaii }\end{array}$ & $\begin{array}{l}8.11 \\
5-6.06 \\
8.02 \\
6.90 \\
8.35 \\
10.94 \\
7.5 \\
9 \\
13-20.6 \\
56 \\
77 \\
9.20 \\
12.9-15.70 \\
6.00-11 \\
6.80 \\
8.75 \\
10.39\end{array}$ & $\begin{array}{l}{[38]} \\
{[39]} \\
{[14]} \\
{[40]} \\
{[41]} \\
{[42]} \\
{[43]} \\
{[44,45]} \\
{[46]} \\
{[25]} \\
{[25]} \\
{[47]} \\
{[48,49]} \\
{[50,51]} \\
{[52]} \\
{[37]} \\
{[29]}\end{array}$ \\
\hline $\begin{array}{l}\text { Food } \\
\text { wastes }\end{array}$ & $\begin{array}{l}\text { Average in the EU } \\
\text { Average in the USA } \\
\text { Dining halls in South-Korea }\end{array}$ & $\begin{array}{l}70-80 \\
72 \\
80\end{array}$ & $\begin{array}{l}{[53]} \\
{[54]} \\
{[55,56]}\end{array}$ \\
\hline
\end{tabular}


Table 4

Moisture content of different type of animal manure.

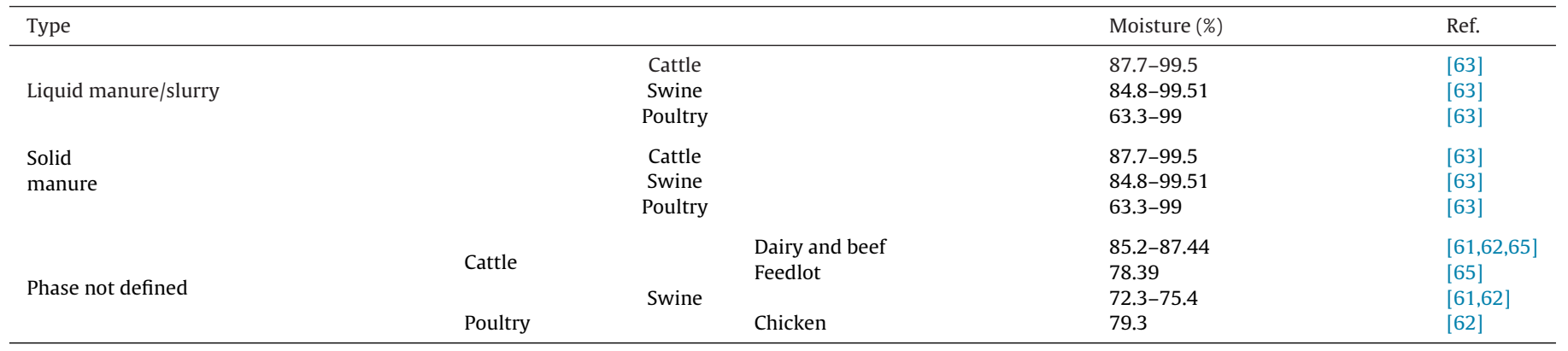

Table 5

Composition of manure based on dry weight in weight \%.

\begin{tabular}{|c|c|c|c|c|c|c|c|}
\hline \multirow[t]{2}{*}{ Type } & & Crude protein & Total amino acids & Total lignocellulose & Hemi-cellulose & Cellulose & Lignin \\
\hline & & $\%$ & $\%$ & $\%$ & $\%$ & $\%$ & $\%$ \\
\hline \multirow[t]{3}{*}{ Cattle manure } & Dairy & 18.1 & 7.92 & 52.6 & 12.2 & 27.4 & 13 \\
\hline & Beef & 12.1 & 7.61 & 51.5 & 17.4 & 21.9 & 12.2 \\
\hline & Feedlot & 17 & 10.89 & 41.7 & 21.4 & 14.2 & 6.1 \\
\hline \multirow[t]{3}{*}{ Swine manure } & Nursery & 25.1 & 16.56 & 39.2 & 21.9 & 13.2 & 4.1 \\
\hline & Grower & 22.7 & 18.99 & 39.1 & 20.4 & 13.3 & 5.4 \\
\hline & Finisher & 22 & 15.63 & 37.4 & 21.6 & 12.9 & 2.9 \\
\hline \multirow[t]{4}{*}{ Poultry manure } & Chick starter & 39.8 & 13.52 & 31.7 & 18.3 & 8.5 & 4.9 \\
\hline & Pullet grower & 48.4 & 17.31 & 36.4 & 21.5 & 7.7 & 7.2 \\
\hline & 17-40 Weekspost-polt diet & 31.6 & 7.61 & 34.5 & 20.2 & 11.1 & 3.2 \\
\hline & Post-molt diet & 28 & 10.61 & 31.2 & 16.4 & 10.7 & 4.1 \\
\hline
\end{tabular}

Table 6

Water consumption in corn-based ethanol plants.

\begin{tabular}{lcc}
\hline Water consumption (liter of water per 1 L of ethanol) & Year & Ref. \\
\hline Average 5.8 & 1998 & {$[77]$} \\
Range 1-11, (average 4.7) & 2002 & {$[78]$} \\
4.2 & 2005 & {$[77]$} \\
4.1 & 2006 & {$[79]$} \\
2.7 & 2008 & {$[80]$} \\
\hline
\end{tabular}

a widely used pretreatment for both ethanol and biogas production [70]. The oldest hydrothermal pretreatment method is cooking of lignocellulosic materials in liquid hot water, used by the pulp industries [71]. The typical concentration of biomass could be between 6 and $20 \mathrm{wt} \%$ [72]. Due to poor reproducibility, the suggested biomass content should be below $5 \mathrm{wt} \%$ involving much higher volume process water. For steam pretreatment the pressure and temperature of steam could be adjusted and the biomass concentration usually $50 \mathrm{wt} \%$ [71].

Alkaline pre-treatment of lignocellulose usually uses 1-2 wt\% $\mathrm{NaOH}$ solution [73] or $10 \mathrm{wt} \%$ ammonia liquor [74] to solubilize the hemicellulose components.

Considering acid catalyzed hydrolysis, sulfuric acid is the most commonly applied acid, though the use of other acids such as $\mathrm{HCl}$ and nitric acid was also reported for all kind of biomass' water content [75]. The acid pretreatment can operate either under a high temperature and low acid concentration or under a low temperature and high acid concentration. [76].

The development of more efficient technologies with respect to the water consumption can be demonstrated by the production of corn-based ethanol using first generation bio-ethanol technology (Table 6). Early data regarding water consumption

in ethanol plants reveal values in the range from 1 to $11 \mathrm{~L}$ of water per a liter of ethanol. Water requirements of the production process could be decreased by energy integration and water optimization including water recycling and zero discharge. By this optimization method the water consumption should be $2.85 \mathrm{~L}$ of water per $1 \mathrm{~L}$ of ethanol [81]. The application of dry mill technologies further decreased the water demand [80]. By 2008, the water requirement of corn ethanol could be decreased to less than the half of the demand of 1998. A recent study has demonstrated the importance of water recycling by using either un-treated or purified grey water (e.g. process water) or green water (e.g. rain water). In this way the consumption of blue water (e.g. fresh water) can be significantly reduced in bio-fuel production technologies [82]. A state-of-the-art corn-based plant could operate with as low as $1.5 \mathrm{~L}$ water per liter ethanol demand [83].

Pacific Northwest National Laboratory developed a fastpyrolysis plant applying hydro-treating and hydrocracking, which would use 2000 dry metric tons/day of hybrid poplar wood chips to produce 320 million liters/year of gasoline and diesel with an estimated water requirement of 3.0 L water for a liter product. Cooling water represents most of water demand, since it is recirculated in the quench system, therefore resulting in a low value [84].

Consumptive water usage in the biochemical conversion process is generally considered to be high compared with a thermochemical conversion process. The biochemical conversion of corn stover was simulated and optimized by researchers in National Renewable Energy Laboratory and a competitive value of $5.4 \mathrm{~L}$ water per liter product was revealed [85].

Water management is a crucial issue in biomass processing technologies and a necessary tool to secure low water consumption in the future.

\subsection{Water as a reaction medium}

Water is a cheap, readily available, nonflammable, non-toxic, and therefore one of the greener solvents. It is especially suitable for reactions involving ionic species, since the water molecules can readily solvate both the anions and cations. Water can serve both as a solvent and a ligand resulting in the reversible coordination to 


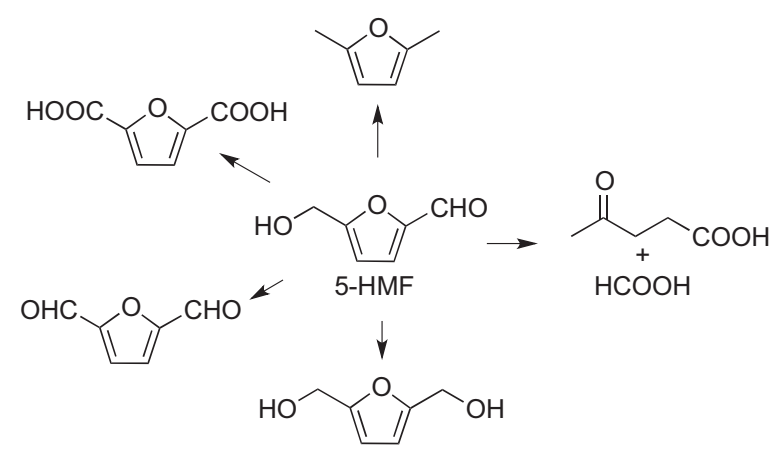

Scheme 1. HMF based chemicals.

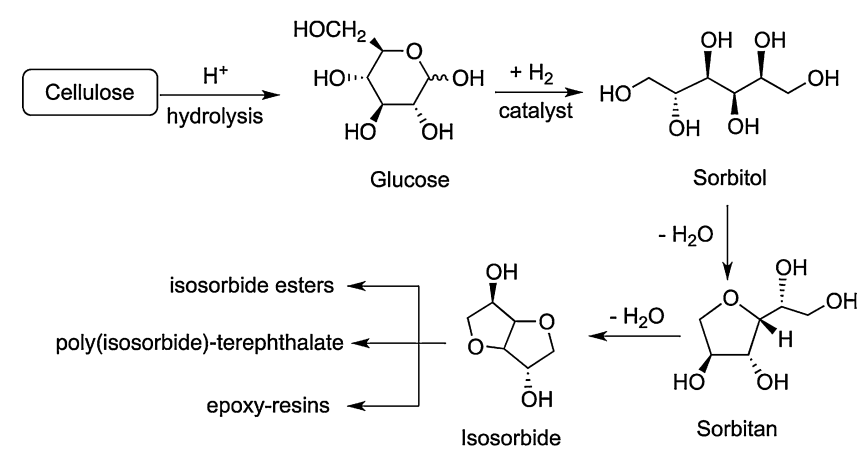

Scheme 2. Multistep conversion of cellulose to isosorbide.

active site(s) of reagents or catalysts. Water is a strong $\sigma$-donor with only a weak back-donating capability. Since water has strong $\mathrm{O}-\mathrm{H}$ bonds which do not permit easy reactions with radicals in solution, it is an attractive medium for radical reactions. A key property of water as a solvent is the stabilization of structures and effecting reaction routes by hydrogen bonding. Water has a limited role in many organic reactions, because it is a poor solvent for organic substrates, and is incompatible with some reagents. It can be the major component in one of the phases in biphasic processes, but the clean-up of the aqueous phase could be a difficult issue.

Water insoluble polysaccharides including starch, cellulose, hemicellulose, and chitin are the main components of biomass. Their hydrolysis could lead to the formation of water soluble monosaccharides, such as glucose, fructose. Similarly, sucrose or ordinary table sugar, consists of a glucose and a fructose, is also highly water soluble. Consequently, water is an excellent solvent

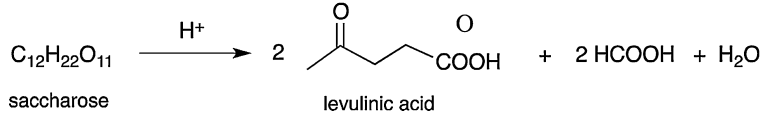

Scheme 4. Formation of levulinic and formic acids from saccharose.

for the catalytic conversion of various mono- and disaccharides. In addition, many of the typical reactions involve either the formation of water or it serves as a reaction partner offering a rare opportunity to include water in the design of the reaction environment.

Different degree of conservation of the constituents of monosaccharides can be achieved by producing various products having the total carbon atoms from 6 to 1 , including 5-hydroxymethyl-2-furaldehyde (5-HMF), isosorbite, levulinic acid (LA), $\gamma$-valerolactone (GVL), succinic, fumaric and maleic acids, n-butanol, acetone, lactic acid, acetic acid, ethanol, syngas $\left(\mathrm{CO} / \mathrm{H}_{2}=1: 1\right)$. While many of these products are produced by fermentation [86], which is beyond the scope of this paper, others have been identified as key platform chemicals [87].

The acid catalyzed conversion of glucose to 5-HMF is one of the most important steps of the valorization of the carbohydrate parts of biomass. 5-HMF has been considered as one of the $\mathrm{C}_{6}$-platform chemicals and can be used for the synthesis of a wide-range of carbon-based chemicals and materials (Scheme 1) [88,89].

Isosorbide, another $C_{6}$-platform chemical [90], can be prepared by a one-pot conversion from cellulose (Scheme 2) using a bifunctional catalytic concept under aqueous conditions. The combination of heteropoly acid $\mathrm{H}_{4} \mathrm{SiW}_{12} \mathrm{O}_{40}$ and the redox catalyst $\mathrm{Ru} / \mathrm{C}$ under 50 bar $\mathrm{H}_{2}$ pressure at $210^{\circ} \mathrm{C}$ resulted in a rapid conversion to isosorbide in $>50 \%$ yield. The robustness of the catalysts system was evidenced by the transformation of a range of impure cellulose pulps derived by organosolv fractionation from native cellulose e.g. hard wood, wheat straw with yields up to 63\% [91].

Isosorbide is one of the monomers of polyethylene isosorbide 2,5-furandicarboxylic acid (PEIF) polymer, synthesized by the polymerization of ethylene glycol, isosorbide, and 2,5furandi-carboxylic acid [92]. Its monomers can be obtained from lignocellulosic biomass especially from cellulose, making PEIF a green and fully bio-based alternative for polyethylene terephthalate (PET) [93].

Due to its reactive functional groups, levulinic acid has been identified as a $C_{5}$-platform chemical (Scheme 3) [94,95]. Its various ester derivatives may be used as gasoline and biodiesel additives. While D-aminolevulinate is a known biodegradable herbicide, its calcium salt is used as intravenous injection as a calcium carrier

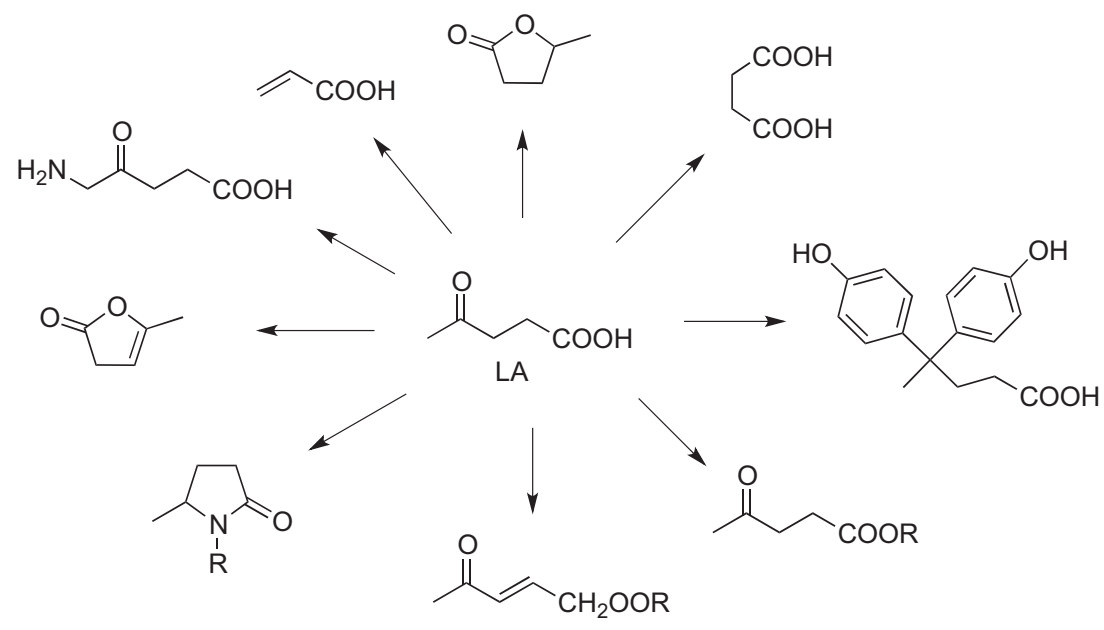

Scheme 3. Levulinic acid derivatives. 
Table 7

Formation of levulinic acid from $\mathrm{C}_{6}$ and $\mathrm{C}_{12}$ sugars.

\begin{tabular}{rlllll}
\hline Entry & Source & Acid & Temp $\left({ }^{\circ} \mathrm{C}\right)$ & $\begin{array}{l}\text { Yield } \\
(\text { mol \%) }\end{array}$ & Referencess \\
\hline 1 & D-Fructose & $\mathrm{HCl}(2 \mathrm{M})$ & 170 & 49 & {$[99]$} \\
2 & D-Fructose & $\mathrm{H}_{2} \mathrm{SO}_{4}(1.8 \mathrm{M})$ & 170 & 42 & {$[99]$} \\
3 & D-Glucose & $\mathrm{HCl}_{(1.8 \mathrm{M})}$ & 170 & 48 & {$[99]$} \\
4 & D-Glucose & $\mathrm{H}_{2} \mathrm{SO}_{4}(2 \mathrm{M})$ & 170 & 40 & {$[99]$} \\
5 & Sucrose & $\mathrm{H}_{2} \mathrm{SO}_{4}(1 \mathrm{M})$ & 125 & 30 & {$[100]$} \\
6 & Sucrose & $\mathrm{H}_{2} \mathrm{SO}_{4}(1.8 \mathrm{M})$ & 140 & 35 & {$[101]$} \\
7 & Sucrose & $\mathrm{HCl}_{2}(2.8)$ & 125 & 43 & {$[99]$} \\
8 & Sucrose & $\mathrm{HBr}^{(1 \mathrm{M})}$ & 125 & 50 & {$[99]$} \\
9 & Cellobiose & $\mathrm{HCl}_{2}(2 \mathrm{M})$ & 170 & 46 & {$[99]$} \\
10 & Cellobiose & $\mathrm{H}_{2} \mathrm{SO}_{4}(2 \mathrm{M})$ & 170 & 34 & {$[99]$} \\
\hline
\end{tabular}

Table 8

Production of levulinic acid from various biomass resources.

\begin{tabular}{|c|c|c|c|c|c|}
\hline Entry & Source & Acid & Temp $\left({ }^{\circ} \mathrm{C}\right)$ & $\begin{array}{l}\text { Yield } \\
\text { (wt\%) }\end{array}$ & References \\
\hline 1 & Cellulose & $\mathrm{HCl}(2 \mathrm{M})$ & 170 & 31 & [99] \\
\hline 2 & Cellulose & $\mathrm{H}_{2} \mathrm{SO}_{4}(2 \mathrm{M})$ & 170 & 23 & [99] \\
\hline 3 & Chitin & $\mathrm{H}_{2} \mathrm{SO}_{4}(2 \mathrm{M})$ & 190 & 21.6 & [99] \\
\hline 4 & Olive tree pruning & $\mathrm{HCl}(10 \mathrm{M})$ & 200 & 18.6 & [102] \\
\hline 5 & Sweet sorghum & $\mathrm{H}_{2} \mathrm{SO}_{4}(2 \mathrm{M})$ & 160 & 31.4 & [103] \\
\hline 6 & Poplar sawdust & $\mathrm{HCl}(10 \mathrm{M})$ & 200 & 21.3 & [102] \\
\hline 7 & Wheat straw & $\mathrm{HCl}(10 \mathrm{M})$ & 200 & 19.3 & [102] \\
\hline 8 & Tobacco chops & $\mathrm{HCl}(10 \mathrm{M})$ & 200 & 5.2 & [102] \\
\hline 9 & Tobacco chops & $\mathrm{H}_{2} \mathrm{SO}_{4}(5 \mathrm{M})$ & 200 & 3.7 & [102] \\
\hline 10 & Water hyacinth & $\mathrm{H}_{2} \mathrm{SO}_{4}(1 \mathrm{M})$ & 175 & 35 & [104] \\
\hline 11 & Wood sawdust & $\mathrm{HCl}(0.5 \mathrm{M})$ & 190 & 9 & [105] \\
\hline 12 & Starch & $\mathrm{HCl}(0.5 \mathrm{M})$ & 200 & 49 & [106] \\
\hline 13 & Corn starch & $\mathrm{HCl}(1.8 \mathrm{M})$ & 162 & 37 & [107] \\
\hline 14 & Pulp slurry & $\mathrm{HCl}(1.8)$ & 160 & 65 & [108] \\
\hline 15 & Sorghum grain & $\mathrm{H}_{2} \mathrm{SO}_{4}(0.8 \mathrm{M})$ & 200 & 32 & [99] \\
\hline
\end{tabular}

[96]. Its bisphenol derivative could be a substitute of bisphenol-A in polymer manufacture [94].

The first synthesis of LA from saccharose in the presence of aqueous $\mathrm{HCl}$ was reported by Mulder in 1840 (Scheme 4) [97].

It is important to emphasize that the theoretical yield of LA formation from $\mathrm{C}_{6}$-sugars is $68.7 \%$. However, the experimental yields are commonly less than the theoretical one due to the formation of humins and/or tar as by-products. The yields of LA from $C_{6}$ and $C_{12}$ sugars were reported to be between 30 and $50 \%$ in the presence of sulfuric or hydrochloric acids; however the latter is more efficient under aqueous conditions (Table 7). Moreover, higher yields could be usually obtained by hydrolyzing feedstock with a higher content of $\mathrm{C}_{6}$-sugars, such as starch or pulp slurry, at high temperatures, as expected (Table 8).

Another important derivative is $\gamma$-valerolactone (GVL), which can readily be obtained by the reduction of LA and has been proposed as a sustainable liquid and fuel [108]. It can be used for the production of transportation fuels, butane isomers [109], octane booster [108], alkanes [100], 2-methyl-tetrahydrofuran [100], pentane-1,4-diol [100,110], ionic liquids [111,112], adipic acid [113], alkyl valerates [111], polymers [114], pentanoic acid [115] or utilized as a solvent [116,117] (Scheme 5).

Since LA is soluble in water, several aqueous systems were developed for the hydrogenation of its carbonyl group that leads to the formation of 4-hydroxyvaleric acid (4-HVA). The latter could readily undergo dehydration to form GVL (Scheme 6). It is important to note that water does not form azeotropic mixture with GVL, thus it can be isolated by simple distillation [108]. Since the increasing importance of GVL, several homogeneous and heterogeneous catalytic systems have been developed successfully for its production.

The first application of water-soluble homogeneous $\mathrm{HRuCl}(\mathrm{TPPMS})_{3}$ catalyst for the reduction of oxo- and keto

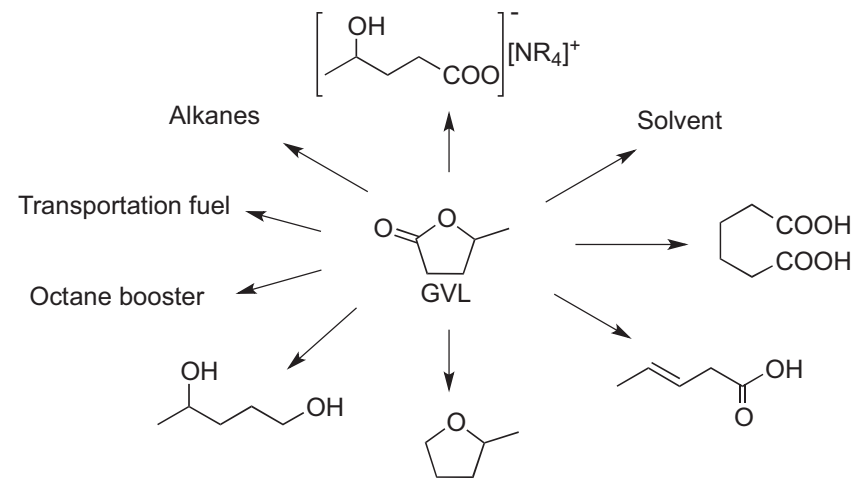

Scheme 5. GVL based chemicals.

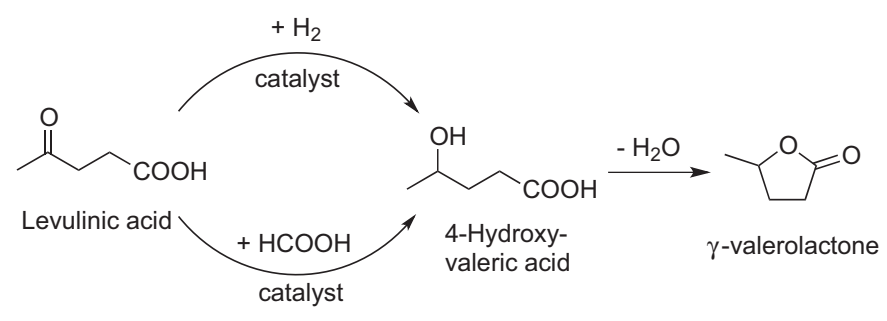

Scheme 6. Reduction of LA to GVL.

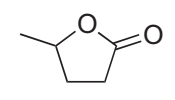

$\gamma$-valerolactone
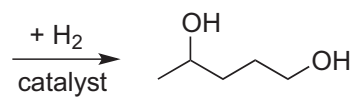

1,4-pentanediol

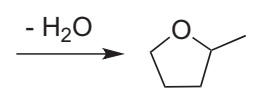

2-methyl-THF
Scheme 7. Conversion of GVL to oxygenates.

acids was reported by Joó et al. years before others [118,119]. However, the catalytic activity was low $\left(\mathrm{TOF}=13 \mathrm{~h}^{-1}\right)$ at $\mathrm{pH}=1$. It was shown that LA could be converted to GVL by the use of $\mathrm{Ru} / \mathrm{TPPTS}$ catalyst in aqueous solution with $95 \%$ yield at $140^{\circ} \mathrm{C}$ [100]. The application of TPPTS modified Ru catalyst in biphasic hydrogenation of $\mathrm{LA}$ in $\mathrm{CH}_{2} \mathrm{Cl}_{2} / \mathrm{H}_{2} \mathrm{O}$ was reported by Heeres et al. resulting in excellent yields under mild conditions; however the conversion was significantly lower (55\%) in the second run of the recycling [120]. Kühn et al. tested the series of water soluble Ru catalyst formed in situ from $\mathrm{RuCl}_{3}$ or $\mathrm{Ru}(\mathrm{acac})_{3}$ and water soluble phosphines such as PTA, TXPS or TPPS. By the use of catalyst loadings of $0.2 \mathrm{~mol} \%$, the product yields were up to $99 \%$ conversion with selectivity of $97 \%$ along with a maximum TOF $=200 \mathrm{~h}^{-1}$ using TPPTS ligands at $140^{\circ} \mathrm{C}$. A ruthenium phosphine complex immobilized on the amphiphilic copolymer PS-PEG was also examined under the same conditions and gave 90\% conversion of LA [121]. Recently, much more active $\left(\mathrm{TOF}=2160 \mathrm{~h}^{-1}\right)$ iridium complexes with 2,2'-bipyridine ligands were reported for the hydrogenation of LA under mild conditions in water using $[\mathrm{LA}]=1 \mathrm{~mol} \mathrm{dm}^{-3}$ initial concentration [122]. However, in spite of the high activity, the final product concentration is less than $1 \mathrm{M}$ and the water-removal step could result in low energy efficiency of the process. It should be noted, that during the catalyst recycling the decrease of GVL yield was negligible for five consecutive runs. It was recently reported that the reduction of LA can be performed under solvent free conditions - the reaction can be initiated in neat LA in the presence of catalyst in situ formed from $\mathrm{Ru}(\mathrm{acac})_{3}(0.016 \mathrm{~mol} \%)$ and 10 fold excess of $\left(\mathrm{C}_{4} \mathrm{H}_{9}\right) \mathrm{P}\left(\mathrm{C}_{6} \mathrm{H}_{4}-m-\mathrm{SO}_{3} \mathrm{Na}\right)_{2}$ ligand under 10 bar of $\mathrm{H}_{2}$ at $140{ }^{\circ} \mathrm{C}$ resulting in TOF of $3540 \mathrm{~h}^{-1}$ [123]. The in situ IR investigation established that the catalyst still remained active after full conversion of LA. The efficiency of the Ru catalyst 


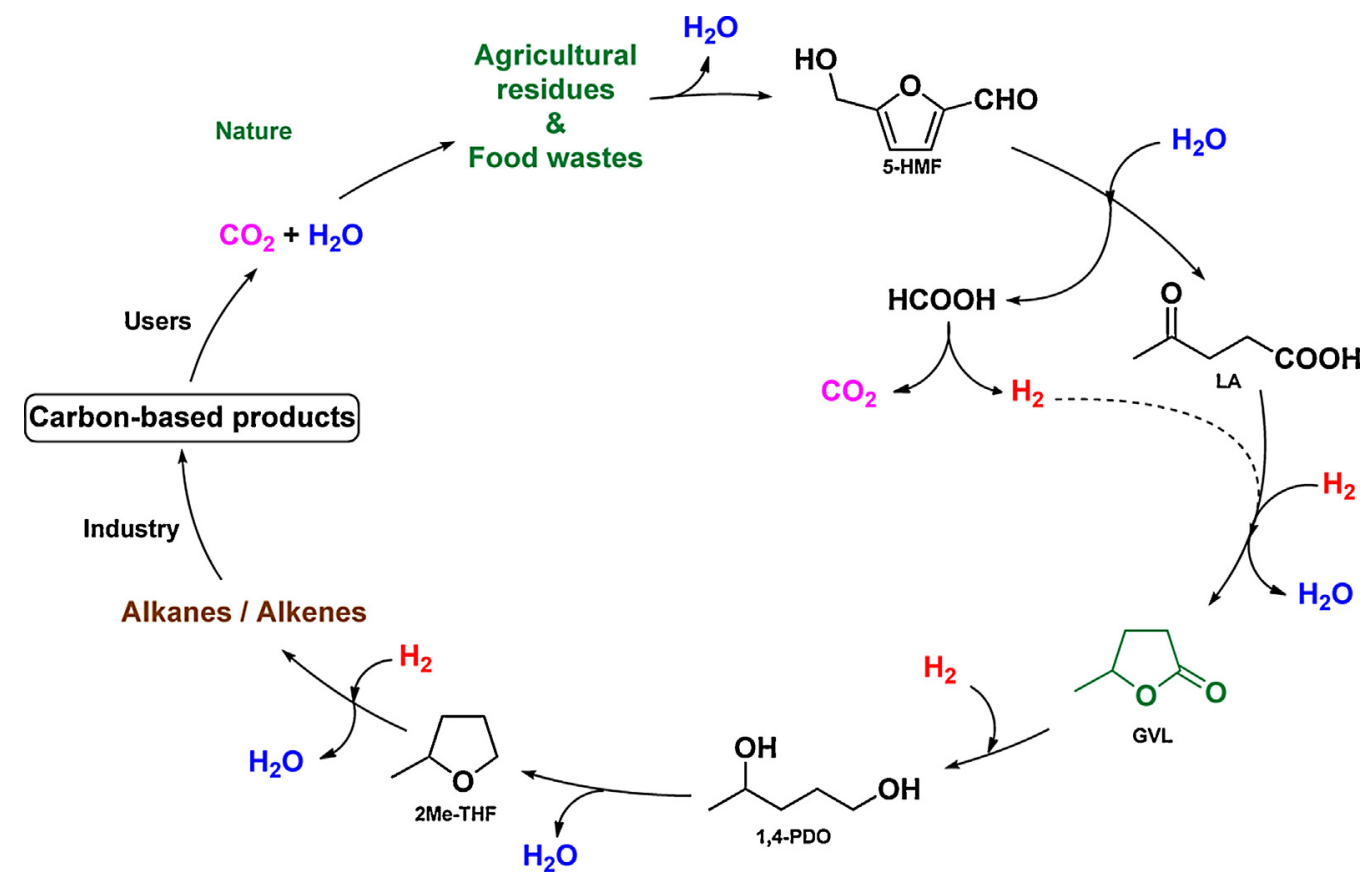

Scheme 8. Multistep conversion of carbohydrates to carbon-based products.

operating under solvent free conditions was further increased up to TOF $=21,230 \mathrm{~h}^{-1}$ by the application of bidentate $\mathrm{Ph}_{2} \mathrm{P}\left(\mathrm{CH}_{2}\right)_{4} \mathrm{PPh}_{2}$ ligand at $160^{\circ} \mathrm{C}[124]$.

It should be noted that the catalytic transfer hydrogenation of LA in the presence of formic acid and the Shvo-catalyst was reported as an alternative, external hydrogen-gas independent route for the production of GVL [125].

Heterogeneous catalytic systems are mainly operated by using supported transition metal catalyst such as $\mathrm{Pd} / \mathrm{C}, \mathrm{Ru} / \mathrm{C}, \mathrm{Ru} / \mathrm{SiO}_{2}$, $\mathrm{Ru} / \mathrm{TiO}_{2}, \mathrm{Ru} / \mathrm{Al}_{2} \mathrm{O}_{3}$ or Raney-Ni under $1-250$ bar $\mathrm{H}_{2}$ at $70-265^{\circ} \mathrm{C}$. Although these catalysts can easily be separated from the reaction mixture, the activity and selectivity are far from the homogeneous ones, as expected [126]. Moreover, these systems do not use water as a solvent, but usually contain co-solvents e.g. alcohols, which may cause separation difficulties [127]. The continuous hydrogenation of aqueous solution of LA to GVL was also reported using $\mathrm{H}-\mathrm{Cube}^{\circledR}$ and $\mathrm{H}-\mathrm{Cube}$ Pro ${ }^{\mathrm{TM}}$ flow reactors, which generates hydrogen gas in situ by the electrolysis of water, then continuously mixed with the substrate. When $\mathrm{Ru} / \mathrm{C}$ was used as catalyst bed in the CatCart ${ }^{\circledR}$, conversion exceeded $97 \%$ with $100 \%$ of selectivity at $1 \mathrm{~mL} / \mathrm{min}$ flow rate at $100^{\circ} \mathrm{C}$ [128].

The subsequent reduction of GVL to 1,4-pentanediol and 2methyl-THF (Scheme 7) and than to $C_{4}, C_{5}, C_{8}$ and $C_{9}$ alkanes was also demonstrated by the use of Ru and Pt-based catalyst systems [100]. Thus, the integrated conversion of the carbohydrate components of agricultural residues and food wastes to value added carbon-based consumer products was demonstrated (Scheme 8) [100].

Succinic, fumaric and maleic acids were identified as $\mathrm{C}_{4^{-}}$ platform chemicals [87]. For example, succinic acid can be produced by fermentation of carbohydrates and used as a feedstock for the production of pharmaceuticals, 1,4-butanediol, $\gamma$-butyrolactone, surfactants and detergents, biodegradable plastics, and ingredients to stimulate animal and plant growth [129]. It has been used for the beverage industry primarily as an acidity regulator for decades. Fumaric acid has been also used as a food additive and it has an important role in the manufacturing the polyester resins.

An aqueous reduction of succinic acids using syngas (Scheme 9) was developed [130]. The conversions were found to be excellent

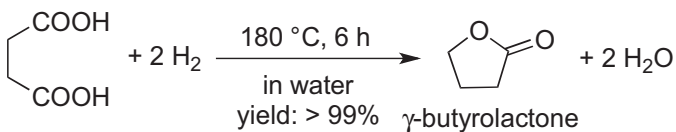

Scheme 9. Conversion of succinic to $\gamma$-butyrolactone.<smiles>O=C(O)C=CC(=O)O</smiles>

Scheme 10. Conversion of fumaric to $\gamma$-butyrolactone.

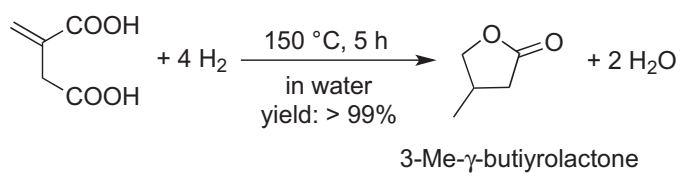

Scheme 11. Hydrogenation of itaconic acid to 3-methhyl- $\gamma$-butyrolactone.

$$
\begin{aligned}
& \mathrm{C}_{6} \mathrm{H}_{10} \mathrm{O}_{5}+\mathrm{H}_{2} \mathrm{O} \longrightarrow 6 \mathrm{CO}+6 \mathrm{H}_{2} \\
& \mathrm{C}_{6} \mathrm{H}_{10} \mathrm{O}_{5}+3 \mathrm{H}_{2} \mathrm{O} \longrightarrow 4 \mathrm{CO}+2 \mathrm{CO}_{2}+8 \mathrm{H}_{2} \\
& \mathrm{C}_{6} \mathrm{H}_{10} \mathrm{O}_{5}+7 \mathrm{H}_{2} \mathrm{O} \longrightarrow 6 \mathrm{CO}_{2}+12 \mathrm{H}_{2}
\end{aligned}
$$

Scheme 12. Cellulose gasification by steam reforming.

in the presence of $\mathrm{Au} / m-\mathrm{ZrO}_{2}$ heterogeneous catalyst operating 20-50 bar at $120^{\circ} \mathrm{C}$. The fastest reduction was achieved, when the partial pressure of hydrogen was higher. Although, the product conversion and selectivity was not affected by the $\mathrm{CO}: \mathrm{H}_{2}$ ratio, the reaction time was longer at lower $p\left(\mathrm{H}_{2}\right)$, expectedly. The catalyst was successfully applied for the reduction fumaric acid, as well. When itaconic acid or lactic acid was reduced the conversions and selectivity were found to be $100 \%$ and $>87 \%$ for the formation of 3-methyl- $\gamma$-butyrolactone and 1,2-propanediol, respectively (Schemes 10 and 11 ). 


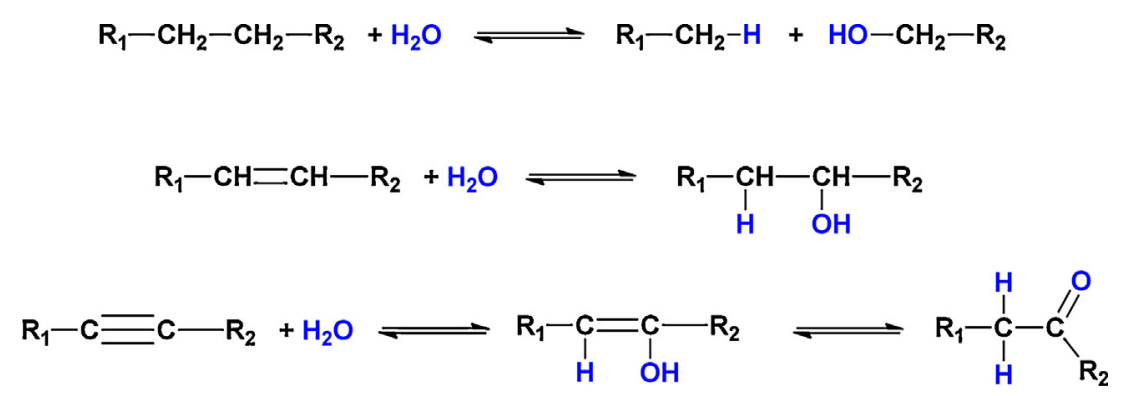

Scheme 13. Hydrolysis, hydration, and dehydration reactions.

Syngas $\left(\mathrm{CO}+\mathrm{H}_{2}\right)$ and biogas $\left(\mathrm{CH}_{4}+\mathrm{CO}_{2}\right)$ are the potential $\mathrm{C}_{1}$ products of biomass conversion. While biogas is produced by meso- or thermophilic microorganisms at moderate temperature through anaerobic digestion [131], syngas is formed at elevated temperatures by the gasification process. Gasification can be carried out in air, pure oxygen and/or steam media generating a gaseous product containing $\mathrm{CO}, \mathrm{H}_{2}, \mathrm{CO}_{2}, \mathrm{CH}_{4}$ and $\mathrm{N}_{2}$ in various proportions [132]. According to Corma, gasification can be carried out in three different ways: partial oxidation (in presence of air), pyrolysis (absence of oxygen), and steam gasification [133]. Of the gasification routes listed on (Scheme 12), steam gasification requires significant amount of water in a form of steam. The product composition depends on the ratio of water.

New approaches of co-gasification of biomass and coal, or partial oxidation and steam reforming of biomass pyrolysis oils were suggested for syngas production and higher $\mathrm{H}_{2} / \mathrm{CO}$ ratio could be achieved by using biomass-derived char technology. An alternative option for syngas generation is the coupled steam hydrogasification of biomass and reforming of methane [134].

\subsection{Fundamental reactions involving water}

Hydrolysis, hydration, and dehydration reactions are the most important transformations involving water (Scheme 13). In the case of carbohydrates, these reactions are usually reversible and could follow each other in the presence of catalysts leading to the formation of a wide range of products.

Cellulose is one the most abundant carbohydrates on the Earth consisting of D-glucose units connected by $\beta(1 \rightarrow 4)$ bonds. The seminal work of Payen in 1839 described the main constituents of wood with the empirical formula of $\mathrm{C}_{6} \mathrm{H}_{10} \mathrm{O}_{5}$, which was named to cellulose [135]. The currently accepted structure of cellulose (Scheme 14) was given by the Nobel-laureate Staudinger in 1922 [136]. The utilization of cellulose as a renewable resource has been

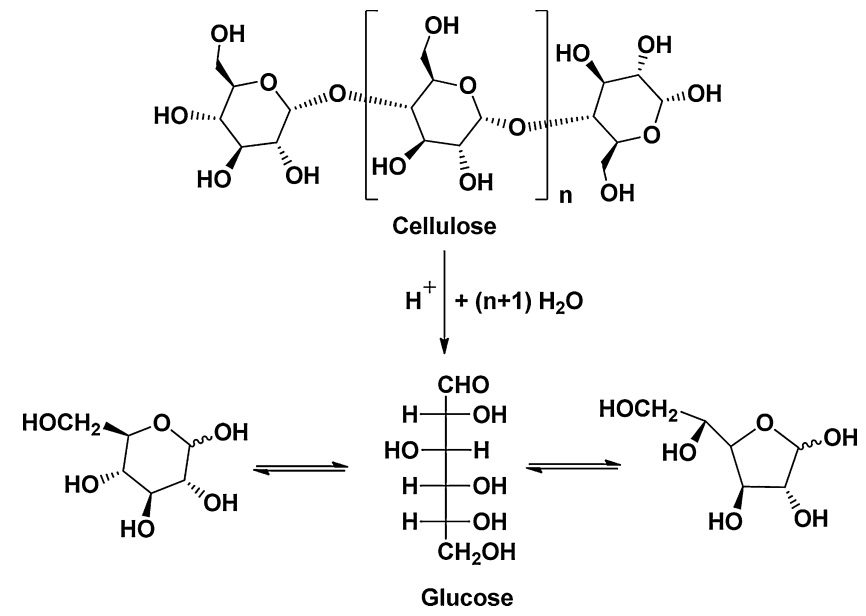

Scheme 14. Conversion of cellulose to glucose. around for a long time. Several processes have been developed for the acid catalyzed dehydration of cellulose for the production of simple sugars that can be fermented to value added products. Typical operation conditions are as follows: $25-240{ }^{\circ} \mathrm{C}$ in the presence of $\mathrm{HCl}, \mathrm{H}_{2} \mathrm{SO}_{4}$, and $\mathrm{HF}$. The mechanism of the hydrolysis of cellulose, which follows a similar pathways as acid catalyzed decomposition of glycosides to glucose was summarized by Schüth in a recent review [137].

The dehydration of carbohydrates to 5-HMF has also been studied for decades [138]. It is well established that the 5-HMF yields are rather low in water and many by-products called "humins" are formed. The solvent dependence of the acid catalyzed dehydration of fructose to 5-HMF has been observed by in situ NMR [89,139]. It was shown that the yield of 5-HMF was the highest in DMSO or THF. The nature of the acid and its concentration is another important factor in the production of 5-HMF [139]. Riisager has developed a novel technique for the synthesis of 5-HMF under aqueous conditions in the presence of $\mathrm{HCl}$ as catalyst resulting in a modest yield of $32 \%$, which can be increased by using short contact time (1 s) at high temperatures $\left(200^{\circ} \mathrm{C}\right)$ [140]. The molecular map of the conversion of fructose to 5 -HMF using ${ }^{13} \mathrm{C}$-labeling technique as well as a detailed in situ characterization of intermediates was reported in 2012 [139]. It was established, that the preferred path of the dehydration proceeds through the fructofuranose isomers (Scheme 15).<smiles>OC[C@H]1O[C@@](O)(CO)[C@@H](O)[C@@H]1O</smiles><smiles>O=C(CO)C(O)C(O)C(O)C(O)CO</smiles><smiles>OC[C@@H]1O[C@H](CO)[C@@H](O)C1O</smiles>

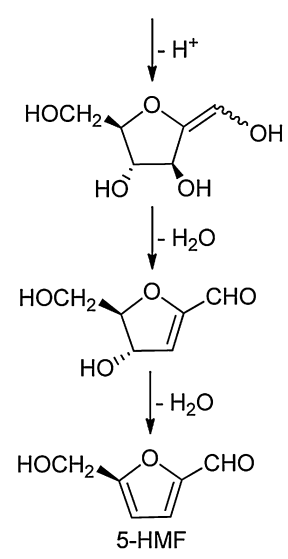

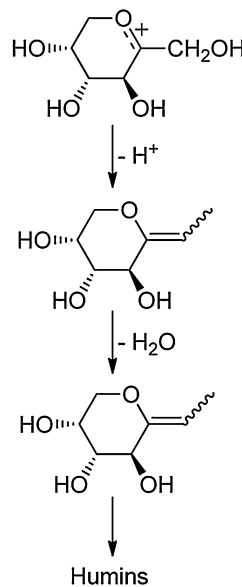

Scheme 15. Conversion of fructose to 5-HMF. 


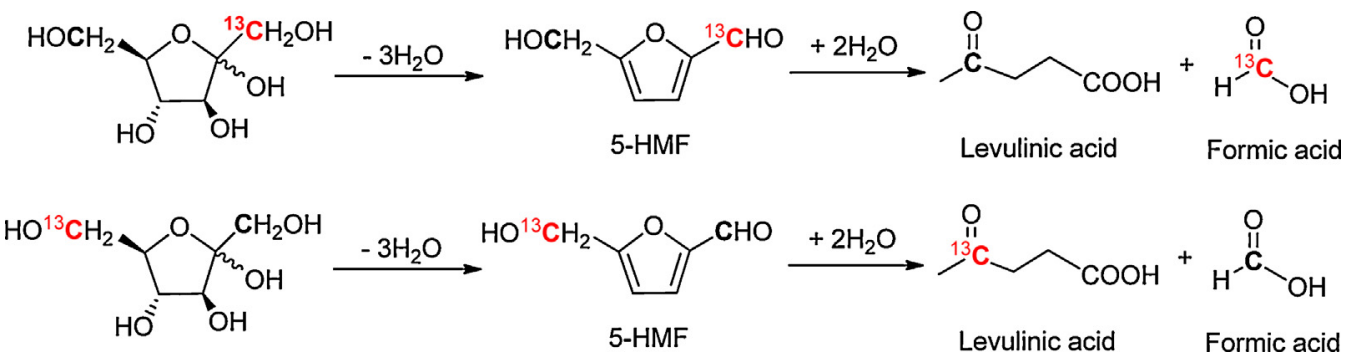

Scheme 16. Conversion of 5-HMF to levulinic and formic acid.

Series of metal halides in 1-alkyl-3-methylimidazolium chloride were found to be an efficient catalysts for the conversion of monosaccharides to 5-HMF, among which chromium (II) chloride was the more efficient resulting in nearly $70 \%$ yield from glucose [141]. It should be noted that only negligible amount of LA was formed. The metal free dehydration of D-glucose and its polymeric forms to 5-HMF were investigated in several solvents including imidazolium based ionic liquids, DMF, and DMSO by the use of boric acid as catalyst [142]. A yield up to $42 \%$ from glucose and $66 \%$ from sucrose was achieved in [BMIM] $[\mathrm{Cl}]$ at $120^{\circ} \mathrm{C}$, significantly higher than by the use of DMSO (13\%). Although, that yields were not higher than that of obtained in the presence of chromium catalysts (70\%) [141], it represents a new class of promoter for the production of 5-HMF.

The first mechanism of the hydration of 5-HMF to the equimolar mixture of levulinic and formic acids was reported in 1985 [143]. A similar study reported for DMSO and $\mathrm{H}_{2} \mathrm{O}$ has verified that the $\mathrm{C}_{1}$ and $\mathrm{C}_{6}$-carbons of $\mathrm{D}$-fructose appears at the corresponding position in 5-HMF [144], which was transferred into the formic acid and the carboxyl group of the levulinic acid, as expected (Scheme 16).

Chitin is the second most abundant biopolymer after cellulose on the Earth (Scheme 17). It is available from the exoskeletons of crustaceans such as crabs, lobsters, shrimps, and in the cell walls of fungi. Although, its formation is exceeded 100 billion tons annually $[145,146]$, the utilization is around 150,000 tons/year [147]. Accordingly, the efficient transformation of this N-containing polymer or its derivatives e.g. chitosan and N-Ac-D-glucosamine (Scheme 17) could be another route for the production of carbon based building blocks and nitrogen containing compounds. Accordingly, the microwave- assisted acid catalyzed hydrolysis was investigated in the presence of both hydrochloric and sulfuric acids resulting in 19-27 wt\% yield of levulinic acid depending on the substrate [98] These reactions require slightly higher temperatures than that of applied for the efficient conversion of lignocellulose or starch. The microwave-assisted conversion of chitosan was also studied in the presence of different of Lewis-acid catalyst in water at $200{ }^{\circ} \mathrm{C}$ [148]. The most efficient catalyst was $\mathrm{SnCl}_{4}$ resulting in 24 wt\% of LA. High 5-HMF selectivities were obtained by the use of different triflates e.g. $\mathrm{La}\left(\mathrm{CF}_{3} \mathrm{SO}_{3}\right)_{3}$ or $\mathrm{Yb}\left(\mathrm{CF}_{3} \mathrm{SO}_{3}\right)_{3}$ and iron perchlorate, however, the yields were below $10 \%$. When the exoskeleton of

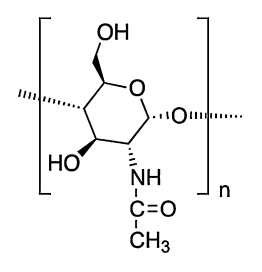

Chitin

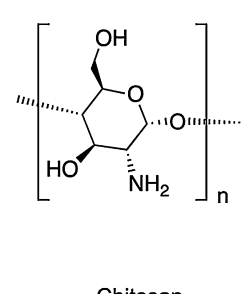

Chitosan

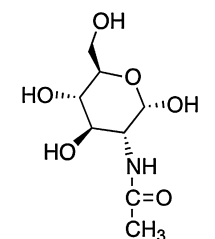

N-Ac-glucosamine
Scheme 17. The structure of chitin, chitosan, and N-acetyl-glucosamine.

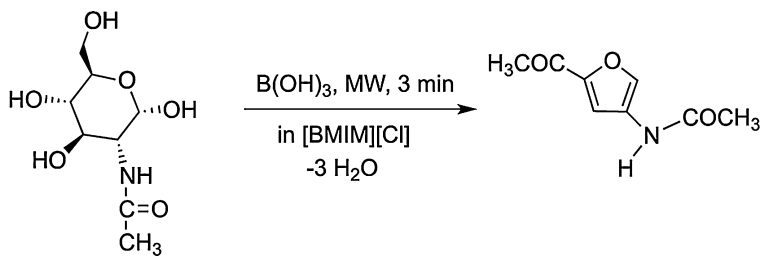

Scheme 18. Synthesis of 3-acetamido-5-acetylfurane.

crab and shrimp was treated at $200{ }^{\circ} \mathrm{C}$, the reactions were selective for LA with average yield of $12.6 \mathrm{wt} \%$.

The direct conversion of $\mathrm{N}$-acetyl-D-glucosamine via dehydration reaction to 3-acetamido-5-acetylfurane was also investigated in several ionic liquids between 120 and 180 (Scheme 18) [149]. It could be a precursor of polyamide proximicines [149] that are isolated from Verrucosispora, a marine actinomycete. The product formation could be accelerated by the addition of different additives - the highest yield of $60 \%$ was achieved when boric-acid was used in $10 \mathrm{~mol} \%$ concentration in [BMIM][Cl] at $180^{\circ} \mathrm{C}$. The kinetic study of the reaction revealed that the activation energy was $82.8 \mathrm{~kJ} / \mathrm{mol}$ [150]. The yield can slightly be increased by the addition of $\mathrm{NaCl}$ and the application of higher temperature $\left(220^{\circ} \mathrm{C}\right)$ [151].

Furfural is another $C_{5}$-platform chemical [152], which can be used for the production of basic chemicals, fuel additives, solvents, etc. (Scheme 19).

Furfural is currently produced from xylose, which can be obtained from hemicellulose via acid catalyzed hydrolysis [152,153]. The application of simple acid-functionalized pyridinium- and ammonium based ionic liquids for the one pot production of furfural from xylose was recently reported [154]. High $(>90 \%)$ xylose conversions and furfural yields $(>70 \%)$ were obtained, when 1-(4-sulfonylbutyl)-pyridinium methanesulfonate was used as catalyst at $150-180^{\circ} \mathrm{C}$ using microwave irradiation at $100 \mathrm{~W}$ for $1 \mathrm{~h}$. The catalyst system was also successfully utilized for the treatment of lignocellulosic waste derived $C_{5}$ syrup produced

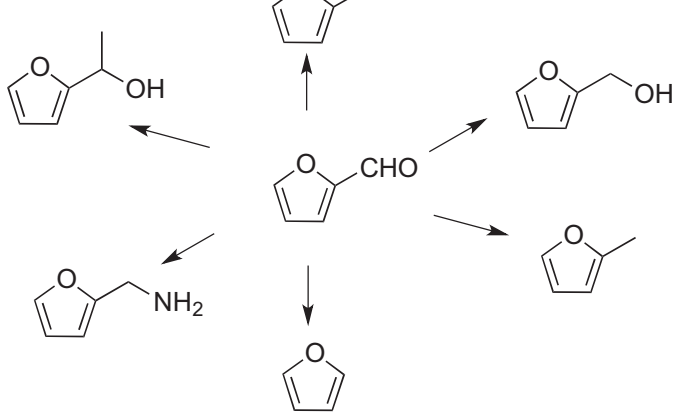

Scheme 19. Furfural based chemicals. 


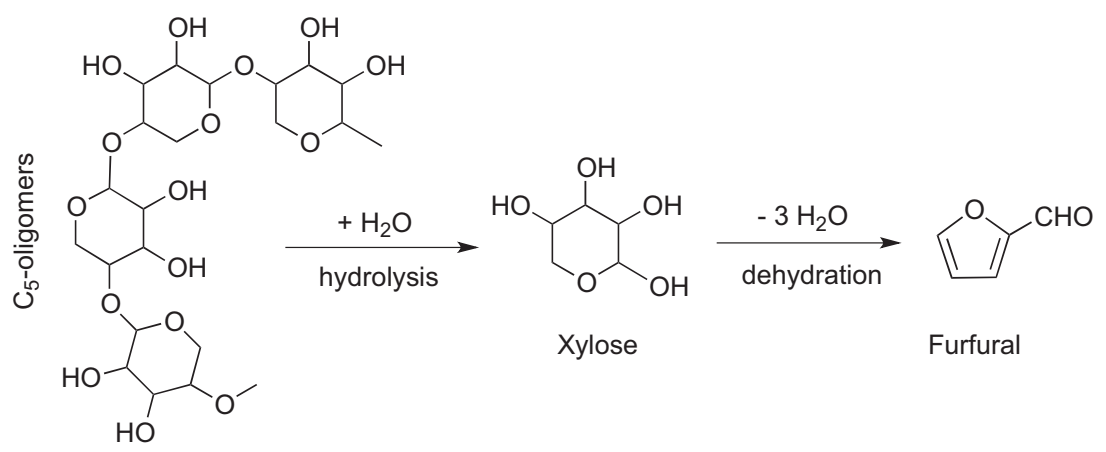

Scheme 20. Conversion of $C_{5}$-oligomers to xylose and furfural.

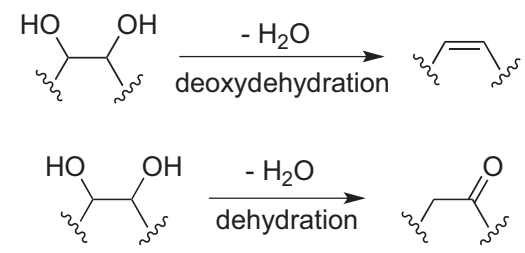

Scheme 21. Competing reactions: deoxydehydration and dehydration.

from cereal straws containing a mixture of sugar monomers (xylose and arabinose, $12 \%$ ), oligomers (30-35\%) and other impurities e.g. proteins, waxes, minerals up to $20 \%$. It was found that the maximum furfural yield of $30 \%$ could be achieved in $30 \mathrm{wt} \%$ aqueous solution at $150^{\circ} \mathrm{C}$ for $2 \mathrm{~h}$. The catalyst containing aqueous phase was separated and reused resulting in same yield in the first run; after which the activity decreased significantly to $14 \%$ in the second catalyst recycle.

A non-catalytic microwave-assisted hydrothermal conversion of xylose to furfural resulted in a moderate yield of $49 \%$ at $200{ }^{\circ} \mathrm{C}$ (Scheme 20) [155]. The conversion of xylan required lower temperatures $\left(160-180^{\circ} \mathrm{C}\right)$ in order to promote the hydrolysis of the polymer and $\mathrm{C}_{5}$-oligomers, yielding xylose instead of furfural.

One of the elegant approaches of the oxygen-rich carbohydrate utilization for the production of simple organic molecules is the deoxydehydration reaction, which eliminates two adjacent $-\mathrm{OH}$ groups from vicinal diol to produce an olefin (Scheme 21). It is important to note that dehydration is a competing transformation leading to a carbonyl compound.

It was demonstrated that various rhenium carbonyls e.g. $\left[\operatorname{Re}_{2}(\mathrm{CO})_{10}, \mathrm{BrRe}(\mathrm{CO})_{5},\left(\mathrm{Cp}^{*} \mathrm{Ru}_{2}(\mathrm{CO})_{2}\right)_{2}\right]$ can deoxygenate diols and epoxydes either in the presence [156] or the absence of secondary alcohol as solvent/reductant [157] or by the use of $\mathrm{H}_{2}$ [158]. $\mathrm{MeReO}_{3}$ [159] can efficiently convert several bio-derived diols or polyols to valuable chemicals under air or $\mathrm{N}_{2}$ at $170-200^{\circ} \mathrm{C}$. Glycerol, which produced in large quantities as by-product of biodiesel production, was converted to allyl-alcohol with excellent yield (90\%) (Scheme 22).

The $\mathrm{C}_{4}$ sugar alcohol erythriol, which can be obtained by the fermentation of glucose [160] or by the decarbonylation of pentoses [161], was converted to 1,3-butadiene in $89 \%$ along with $11 \%$ 2,5-dihydrofurane as the by-product (Scheme 23) and neither 1,4 -anhydroerithriol nor unsaturated alcohols were formed. When racemic DL-threitol was subjected to deoxygenation under identical

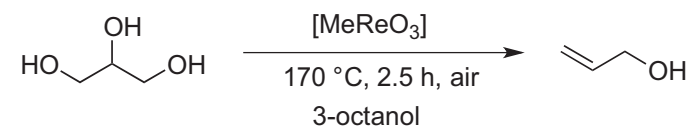

Scheme 22. Conversion of glycerol to allyl-alcohol.

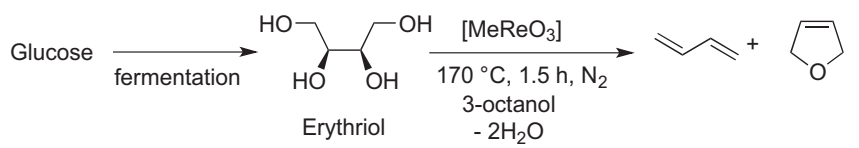

Scheme 23. Glucose based synthesis of 1,3-butadiene via erythriol.

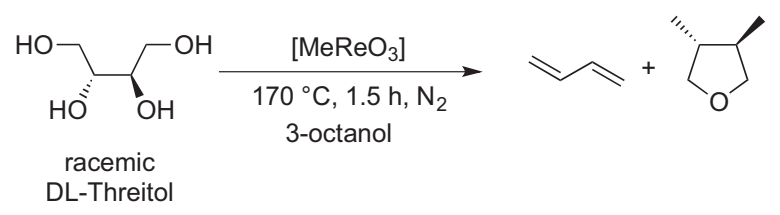

Scheme 24. Deoxygenation of racemic-threitol.

conditions, 1,3-butadiene was obtained with similar yields, however racemic mixture of 1,4-hydroerithriol was formed instead of 2,5-DHF (Scheme 24). The use of $\mathrm{MeReO}_{3}$ was successfully extended to the conversion of $\mathrm{C}_{5}$-sugar alcohols, such as xylitol, to 1,3-diene ether derivatives. If D-sorbitol or D-mannitol were used as the $\mathrm{C}_{6}$-sugar alcohols, deoxydehydration resulted in $E$-hexatriene in moderate yield (54\%).

Interestingly, when different inositol isomers were treated under similar conditions, the mixture of benzene and phenol was obtained in yields between $24-96 \%$. It should be noted, that the conversion of higher alcohols requires higher temperature $\left(200^{\circ} \mathrm{C}\right)$ than that of applied for either diols or glycerol.

The hydrogenolysis of polyols such as glycerol is one possible route for the production of oxygenated chemicals including ethylene glycol (EG), propylene glycol (PG), and lactic acid. EG and $P G$ have industrial importance for the production of polymers, resins, foods, cosmetics, and functional fluids (antifreeze, deicing). Although, lactic acid and its salts have relevance in the food and beverage industry, the greatest opportunity for the use of lactic acid is the production of polylactic acid. The efficiency of heterogeneous supported transition metal catalysts for the hydrogenolysis of polyols to lower molecular weight glycols and acids have been demonstrated by several studies [162-165]. Furthermore, the addition of base has been reported to enhance the conversion of polyols [166]. For the mechanism of hydrogenolysis of glycerol both glyceraldehyde-based [167] and dehydration-hydrogenation mechanism have been proposed [168].

Tranformation of glycerol to EG and PG glycol was studied by the use of carbon-supported Ru and Pt catalysts under 40 bar $_{2}$ at $200{ }^{\circ} \mathrm{C}$ - ruthenium was more active than platinum at neutral $\mathrm{pH}$. Ru-based catalysts favored the formation of EG over PG but also catalyzed the formation of methane. The less active Pt catalyzed propylene glycol formation with high selectivity (Scheme 25) [169].

The conversion of xylitol to EG/PG as main products was reported in the presence of supported Ru catalyst on activated 


$$
\underbrace{\mathrm{OH}}_{\mathrm{H}_{2} \mathrm{O}} \stackrel{\mathrm{H}_{2} / \mathrm{Ru} \text { or Pt }}{\mathrm{HO}} \underbrace{\mathrm{OH}}_{\mathrm{EG}}+\underset{\mathrm{PG}}{\mathrm{OH}}+\underset{\text { Lactic acid }}{\mathrm{OHO}}
$$

Scheme 25. Deoxygenation of glycerol to glycols

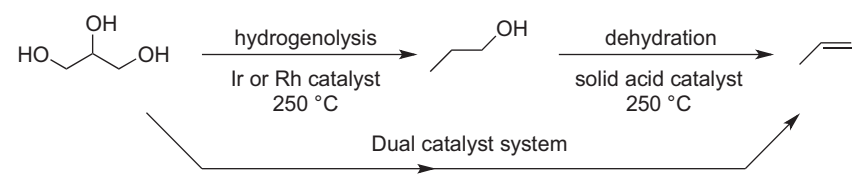

Scheme 26. Production of propylene from glycerol.

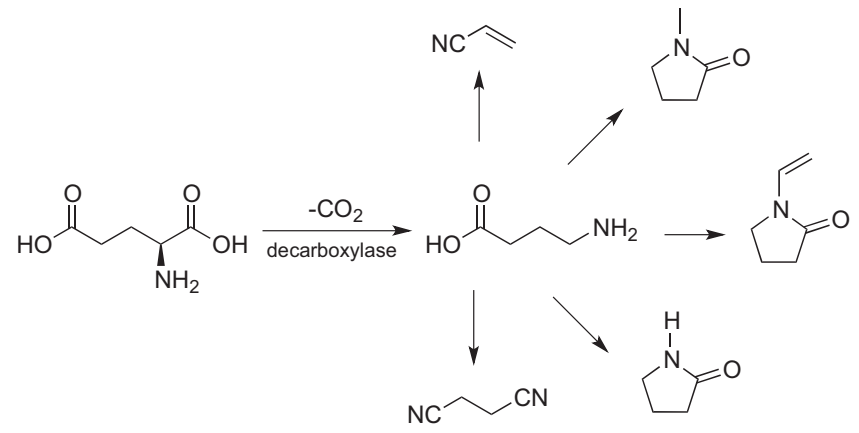

Scheme 27. Utilization of glutamic acid-based gamma-aminobutyric acid.

carbon $(\mathrm{Ru} / \mathrm{C})$ or on metal oxides $\left(\mathrm{Ru} / \mathrm{Al}_{2} \mathrm{O}_{3}, \mathrm{Ru} / \mathrm{Mg}_{2} \mathrm{AlO}{ }_{x}, \mathrm{Pt} / \mathrm{C}\right.$ etc.) under aqueous conditions in the range of $1-10$ bar $\mathrm{H}_{2}$ and $140-260^{\circ} \mathrm{C}$. The maximum selectivity for glycols were obtained at $20-40$ bar $\mathrm{H}_{2}$ and $200-220^{\circ} \mathrm{C}$. Interestingly in the absence of hydrogen, lactic acid was detected as the main product. The selectivities could be also influenced by the addition of bases such as $\mathrm{Ca}(\mathrm{OH})_{2}$ or $\mathrm{Mg}(\mathrm{OH})_{2}$. Moreover, no significant decreases in the activity and selectivity were found, when $\mathrm{Ru} / \mathrm{C}$ was recycled for six consecutive runs (Scheme 26) [170].

The two-step conversion of glycerol to 1-propanol and propylene was recently reported. The first hydrogenolysis step utilized metal-oxides- and carbon-supported Ir and Rh catalysts followed by dehydration over various solid acid catalysts. Direct conversion of glycerol into propylene over $\mathrm{Ir} / \mathrm{ZrO}_{2}$ coupled with $\mathrm{HZSM}-5-30$ was successfully achieved [171].

Important chemicals could be obtained by the conversion of proteins [172]. For example, the hydrolysis of many plants and animal proteins could result in glutamic acid, the most abundant, non-essential amino acid [173]. The most important derivatives of glutamic acid are $\gamma$-aminobutyricacid [174], $N$-vinylpyrrolidone and $N$-methylpyrrolidone [175], acrylonitrile [176], and succinonitrile (Scheme 27) [177]. Similarly, L-lysine could have an important

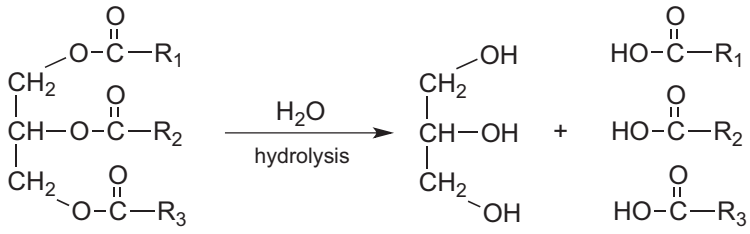

Scheme 29. Hydrolysis of triglycerides.

role on the biomass based production of 1,5-diaminopentane [178], caprolactam [179] and 5-amino-valericacid [180].

The selective hydrolysis of L-arginine to L-ornithine was performed by the use of Bacillus subtilis arginase in a continuously stirred membrane reactor system resulting in an outstanding activity $\left(\mathrm{TON}=1.13 \times 10^{8}\right)$ at $\mathrm{pH}$ of arginine free base 11.0 . It can be further increased to TON $=10^{9}$ by the addition of sodium-dithionite to the substrate solution [181]. It was demonstrated that the hydrolysis of L-arginine to L-ornithine and urea could be a key step in the biomass-based production of 1,4-diaminobutane, a monomer of nylon manufacture. L-arginine has become a widely available resources from biomass waste streams via the nitrogen storage polypeptide cyanophycin (Scheme 28).

Fatty acids that include all saturated and unsaturated aliphatic carboxylic acids with carbon chain lengths in the range of $C_{6}-C_{24}$ can be applied in various sectors of industry as the acids themselves or in the form of derivatives e.g. esters, alcohols, soaps, detergents, amides [182]. Accordingly novel strategies for greener production of biodiesel and platform chemicals from second generation triglyceride feedstocks such as non-edible plant oils, algal oil or waste cooking oils and fats - have come to focus of interest. The catalytic hydrolysis produces a mixture of glycerol and fatty acids (Scheme 29).

Currently, they are produced from the reaction of oils and/or animal fats using superheated steam. Typically, the reactions are carried out at $100-260^{\circ} \mathrm{C}$ and $1-70$ bar using a $0.4-1.5 \mathrm{wt} \%$ waterto-oil ratio [183]. Different variations of this technology have been used by industry and are normally referred to as fat splitting [182,184-187]. The use of a subcritical water, which can act as both solvent and reagent for the hydrolysis of triglyceride [183,188], has been proven to be effective for hydrolyzing soybean oil to free fatty acids resulting in rapid splitting of triglicerides at temperature range of 330 and $340{ }^{\circ} \mathrm{C}$ yielding $97 \%$ or higher conversion without the need of catalysts or emulsifying agents [184]. The subcritical water-assisted splitting was also reported - the conversion of the esters to free fatty acids exceeding $95 \%$ was achieved at $340^{\circ} \mathrm{C}$ [189]. The application of IR study on the hydrolysis revealed structural changes in the chains of the unsaturated fatty acids and their partial polymerization during the hydrolysis.
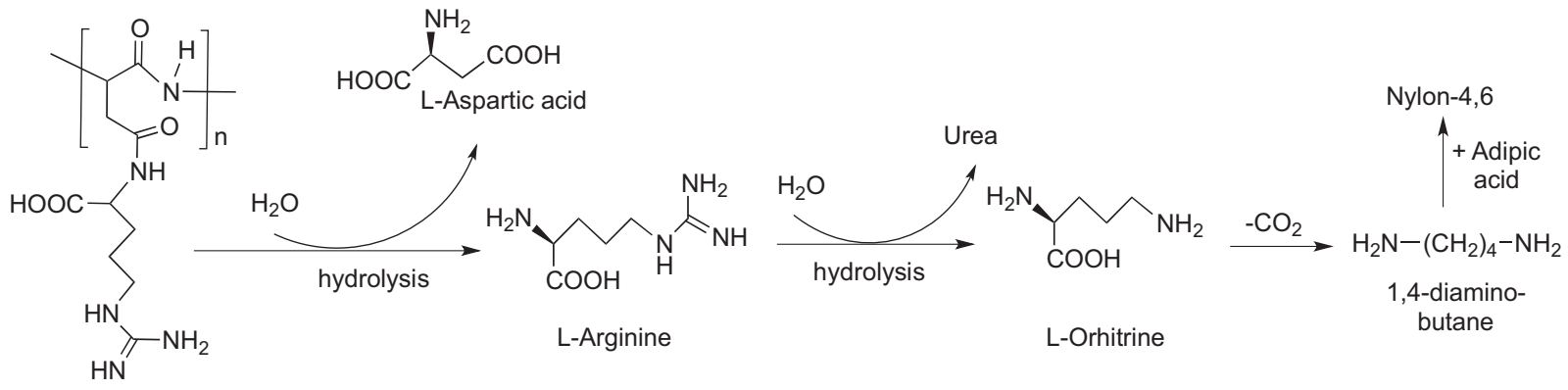

Cyanophycin 


\section{Conclusion}

Water can have many different roles in catalytic biomass-based technologies to produce chemicals and fuels. First and foremost, water is one of the two basic chemicals of nature used during photosynthesis to produce biomass. Consequently, biomass contain different amounts of water, which can be advantageously utilized during the conversion schemes. Water could be the solvent of the reactions or just either the eliminated product or the reactant resulting in hydration and hydrolysis. Since some of these roles are intrinsically part of the natural system, their change could be very difficult or even not possible. Therefore, the designer of the chemistry or the process must understand the possible roles of water at the molecular and macroscopic levels, which indeed requires a genuine collaboration of biologists, chemists and engineers.

\section{Acknowledgments}

This work was partially funded by the Innovation and Technology Support Program of the Innovation and Technology Fund of the Government of the Hong Kong Special Administrative Region, project number ITS/079/13. Any opinions, findings, conclusions or recommendations expressed in this material (or by members of the project team) do not reflect the views of the Government of the Hong Kong Special Administrative Region, the Innovation and Technology Commission or the Panel of Assessors for the Innovation and Technology Support Program of the Innovation and Technology Fund. The support of Bólyai János Research Scholarship of the Hungarian Academy of Sciences is also acknowledged.

\section{References}

[1] S. Morgan, The Water Cycle, The Rosen Publishing Group Inc, New York, 2009.

[2] G.N. Somero, C.B. Osmond, C.L. Bolis, Water and Life: Comparative Analysis of Water Relationship at the Organismic, Cellular, and Molecular Levels, Springer, London, 2011.

[3] C.J. Li, Reactions in water, in: P.T. Anastas (Ed.), Handbook of Green Chemistry - Green Solvents, vol. 5, Wiley-VCH, Mainheim, 2013.

[4] S. Kobayashi, Water in Organic Synthesis, Georg Thieme Verlag KG, Stuttgatd and New York, 2012.

[5] Q. Bone, R.H. Moore, Biology of Fishes, in: third ed., Taylor \& Francis Group, New York, 2008.

[6] D.Zetland, The End of Abudance: Economic Solutions to Water Scarcity, Aguanomics Press, 2011.

[7] P.T. Anastas, J.C. Warner, in: I.T. Horváth, P.T. Anastas (Eds.), Green Chemistry: Theory and Practice, Oxford University Press, Oxford, 1998 (Chem. Rev. (107) 2007, 2169).

[8] J.H. Clark, F.E.I. Deswarte, Introduction to Chemicals from Biomass, Wiley, Chichester, 2008.

[9] Ministry of Agriculture, Food and rural affairs, Ontario, Canada, 2014, Available from: http://www.omafra.gov.on.ca/english/crops/pub811/1 corn.htm (accessed 28.06.14)

[10] T.R. Miles, T.R. Miles Jr., L. Baxter, R.W. Bryers, B.M. Jenkins, L.L. Oden, Alkali deposits found in biomass power plants. A preliminary investigation of their extent and nature, NREL/TP-433-8142, Appendix C6, 1995.

[11] C. Wilén, A. Moilanen, E. Kurkula, Biomass feedstock analyses, VTT publications 282, Espoo, 1996.

[12] T.R. Miles, T.R. Miles Jr., L. Baxter, R.W. Bryers, B.M. Jenkins, L.L. Oden, Alkali deposits found in biomass power plants. A preliminary investigation of their extent and nature, NREL/TP-433-8142Appendix C5, 1995.

[13] F.A. Agblevor, S. Besler-Guran, D. Montane, A.E. Wiselogel, in: A.V. Bridgwater, D.G.B. Boocock (Eds.), Biomass Feedstock Variability and its Effect on Biocrude Oil Properties, vol. 1, 2000, pp. 741-755.

[14] Y.J. Lu, L.J. Guo, C.M. Ji, X.M. Zhang, X.H. Hao, Q.H. Yan, Int J Hydrogen Energy 31 (2006) 822.

[15] O. Kitani, C.W. Hall:, Biomass Handbook, Gordon and Breach Science Publishers, New York, 1989.

[16] T.R. Miles, T.R. Miles Jr., L. Baxter, R.W. Bryers, B.W. Jenkins, L.L. Oden, Alkali deposits found in biomass power plants. A preliminary investigation of their extent and nature, NREL/TP-433-8142, Appendix C7, 1995.

[17] W.R. Livingston: Straw ash characteristics, Babcock Energy Limited, DE92 519748, 23 p. (1991).

[18] J.S. Tumuluru, S. Sokhansanj, C.T. Wright, R.D. Boardman, N.A. Yancey, A Review on Biomass Classification and Composition, Co-firing Issues and Pretreatment Methods, in: An ASABE Meeting Presentation, 2011, p. 1110458, Paper Number.
[19] Ministry of Agriculture, Food and Rural Affairs, Ontario, Canada, http:// www.omafra.gov.on.ca/english/crops/pub811/1 harvesting.htm (accessed 28.06.14).

[20] K.J. Hellevang, North Dakota State University of Agriculture and Applied Science, Extension Service, AE-905, 1995, Available from: http://www.ag.ndsu. edu/extension-aben/documents/ae905.pdf (accessed 28.06.14).

[21] K.J. Hellevang, NDSU Extension Service, AE701, 3, 2013, Available from: http://www.ag.ndsu.edu/pubs/plantsci/smgrains/ae701.pdf (accessed 28.06.14).

[22] Conversion of grain to standard market moisture content and weight, http://www.fficorp.com/docs/pdfs/page19.pdf (accessed 28.06.14).

[23] Barley planting, nutrition and harvesting, Dept. of Agriculture, Fisheries and Forestry, Queensland Government, Australia, http://www.daff.qld.gov.au/ plants/field-crops-and-pastures/broadacre-field-crops/barley/plantingnutrition-harvesting (accessed 28.06.14).

[24] D. Mamma, P. Christakopoulos, D. Koullas, D. Kekos, B.J. Macris, E. Koukios, Biomass Bioenergy 8 (1995) 99.

[25] E. Billa, D.P. Koullas, B. Monties, E.G. Koukios:, Structure and composition of sweet sorghum stalk components, Ind. Crops Prod. (1997) 297-302, 6-3/4.

[26] National Corngrowers Association, J. McLaren, StrathKirn Inc., Sugarcane as a Feedstock for Biofuels: An Analytical White Paper, http://www.ncga.com/ upload/files/documents/pdf/sugarcanewhitepaper092810.pdf (accessed 01.07.14).

[27] L. Canilha, A.K. Chandel, T.S. dos Santos Milessi, F.A. Fernandes Antunes, W.L. da Costa Freitas, M. das Graças Almeida Felipe, S.S. da Silva, J. Biomed. Biotechnol. (2012) 1, 2012.

[28] Ministry of Agriculture, Food and Rural Affairs, Ontario, Canada http://www.omafra.gov.on.ca/english/crops/pub811/7other.htm\#sunflower (accessed 28.06.14).

[29] T.R. Miles, T.R. Miles Jr., L. Baxter, R.W. Bryers, B.M. Jenkins, L.L. Oden, Alkal deposits found in biomass power plants. A preliminary investigation of their extent and nature, NREL/TP-433-8142, Appendix C5, 1995.

[30] S.O. Serna-Saldívar, C. Chuck-Hernández, E. Pérez-Carrillo, E. Heredia-Olea, in: M.A.P. Lima, A.P.P. Natalense (Eds.), Sorghum as a Multifunctional Crop for the Production of Fuel Ethanol: Current Status and Future Trends in Bioethanol, M. A. P. Lima and A. P. P. Natalense, Chapter 3, InTech, 2012, Available from: http://www.intechopen.com/books/bioethanol (accessed 01.07.14).

[31] L. Liang, R. Xu, Q. Li, X. Huang, Y. An, Y. Zhang, Y. Guo, in: M.A.P. Lima, A.P.P. Natalense (Eds.), Bioethanol, Chapter 4, InTech, 2012.

[32] S.Y. Lee, J.H. Park, S.H. Jang, L.K. Nielsen, J. Kim, K.S. Jung, Biotechnol. Bioeng $101(2008) 209$.

[33] F.A.C. Martinez, E.M. Balciunas, J.M. Salgado, J.M.D. González, A. Converti, R.P. de Souza Oliveira, Trends Food Sci. Technol. 30 (2013) 70.

[34] CEN-335 Biomass standard, Solid biofuels, fuel specifications and classes, 2003, March, Available from: http://www.biomassenergycentre.org.uk/ (accessed 21.07.14).

[35] J.S. Tumuluru, S. Sokhansanj, C.T. Wright, R.D. Boardman, N.A. Yancey, A Review on biomass classification and composition, co-firing issues and pretreatment methods, An ASABE Meeting Presentation (2011) 1110458, Paper Number.

[36] European Biomass Industry Association, Biomass Characteristics, 2014 Available from: http://www.eubia.org/index.php/about-biomass/biomasscharacteristics (accessed 29.06.14).

[37] T.R. Miles, T.E. Miles Jr., L. Baxter, R.W. Bryers, B.M. Jenkins, L.L. Oden, Alkal deposits found in biomass power plants. A preliminary investigation of their extent and nature, NREL/TP-433-8142Appendix C3, 1995.

[38] C. Igathinathane, A.R. Womac, S. Sokhansanj, L.O. Pordesimo, Trans ASAE 48 (2005) 1449.

[39] R.J. Evans, A.R. Knight, M. Onischak, S.P. Babu:, Development of Biomass Gasification to Produce Substitute Fuels, Pacific Northwest Laboratory (PNL), Richland, Washington, USA, 1988, pp. 14, PNL-6518.

[40] S. Naik, V.V. Goud, P.K. Rout, K. Jacobson, A.K. Dalai, Renewable Energy 35 (2010) 1624.

[41] C. Wilén, A. Moilanen, E. Kurkula, Biomass Feedstock Analyses, vol. 282, VTT Publications 282, Espoo, 1996.

[42] R. Miles, T.R. Miles Jr., L. Baxter, R.W. Bryers, B.M. Jenkins, L.L. Oden, Alkal deposits found in biomass power plants. A preliminary investigation of their extent and nature, NREL/TP-433-8142, Appendix C7, 1995.

[43] P. Thy, B.M. Jenkins, C.E. Lesher, S. Grundvig, Fuel Process Technol. 87 (2006) 383.

[44] M.M. Nassar:, Thermal analysis kinetics of bagasse and rice straw, Energy Sources 20 (1998) 831.

[45] R.R. Bakker, B.M. Jenkins, R.B. Williams, D. Pfaff, Fluidized bed combustion of leached rice straw, in: Proc. 4th biomass conference of the Americas, 1999 pp. $1425-1431$.

[46] J. Robak, M. Janusz, A. Sobolewski, Chemik 66 (2012) 436.

[47] S.K. Sharma, K.L. Kalra, H.S. Grewal:, Enzymatic saccharification of pretreated sunflower stalks, Biomass Bioenergy (2002) 237-243, 23-3.

[48] W.R. Livingston, Straw Ash Characteristics, Babcock Energy Limited, 1991, pp. 23 (DE92 519748).

[49] K. Singh, H. Honig, M. Wermke, E. Zimmer:, Fermentation pattern and changes in cell wall constituents of straw-forage silages, straws and partners during storage, Animal Feed Sci. Technol. 61 (1996) 137-153, 1-4.

[50] E. Kurkela, Formation and removal of biomass-derived contaminants in fluidized-bed gasification processes, 287, VTT Publications, Espoo, Finland, VTT, 1996, $47 \mathrm{p}$. 
[51] A.E. Ghaly, A. Ergüdenler, E. Laufer, Agglomeration characteristics of alumina sand-straw ash mixtures at elevated temperatures, Biomass Bioenergy 5 (6) (1993) 467-480.

[52] R. Zanzi, K. Sjöström, E. Bjornbom:, in: A.V. Bridgwater, D.G.B. Boocock (Eds.), Rapid Pyrolysis os Straw at High Temperature, vol. 1, 2000, pp. 61-66.

[53] Europen Paliament, Technology options for feeding 10 billion people: recycling agricultural, forestry $\&$ food wastes and residues for sustainable bioenergy and biomaterials, Study, September 2013, page 21, 2013, Available from: http://www.ieep.eu/assets/1275/Recycling_agricultural_forestry_food wastes_and_residues_for_sustainable_bioenergy_and_biomaterials_-_report. pdf (accessed 01.07.14).

[54] D.M.D. Gray, P. Suto, C. Peck, Anaerobic Digestion of Food Waste, EPA-R9WST-06-004, 2008, ES-3.

[55] S.K. Han, H.S. Shin, Biohydrogen production by anaerobic fermentation of food waste, Int. J. Hydrogen Energy 29 (2004) 569

[56] S.H. Kwon, D.H. Lee, Evaluation of Korean food waste composting with fedbatch operations I: using water extractable total organic carbon content (TOCw), Process Biochem. 39 (2004) 1183.

[57] M.J. Taherzadeh, K. Karimi, Int. J. Mol. Sci. 9 (2008) 1621.

[58] H.G. Qiu, S.P. Liao, J. Yue, L. Jiang, Environ. Sci. 34 (2013) 2766.

59] C. Fulhage, J. Harner, Slurry Manure Collection and Handling Systems, Extension, 2014

[60] P. Nowak, P.E. Cabot, K.G. Karthikeyan, F.J. Pierce, Manure distribution patterns, operator decisions, and nutrient management plans, in: Symposium State of the Science Animal Manure and Waste Management, January 5-7, San Antonio, Texas, Conference Proceeding, L.19, 2005, Availble from: http://www.cals.ncsu.edu/waste_mgt/natlcenter/sanantonio/Nowak.pdf (accessed 22.07.14)

[61] K. Wang, X. Li, C. He, C.-L. Chen, J. Bai, N. Ren, J.-Y. Wang, Bioresource Technol. (2014), http://dx.doi.org/10.1016/j.biortech.2014.03.129 (in press).

[62] D. Yin, W. Liu, N. Zhai, G. Yang, X. Wang, Y. Feng, G. Ren, Bioresource Technol. $166(2014) 373$.

[63] M.P. Bernal, J.A. Alburquerque, R. Moral, Bioresource Technol. 100 (2009) 5444.

[64] R.O. Hegg, Trends in animal manure management research: CHRIS Data Base, in: Symposium State of the Science Animal Manure and Waste Management, January 5-7, 2005, San Antonio, Texas, Conference Proceeding, L.2, 2005, Available from: http://www.cals.ncsu.edu/waste_mgt/natlcenter/ sanantonio/Richard\%20Hegg(Trends).pdf (accessed 22.07.14).

[65] S. Chen, J.H. Harrison, W. Liao, D.C. Elliott, C. Liu, M.D. Brown, Z. Wen, A.E. Solana, R.L. Kincaid, D.J. Stevens, Value-Added Chemicals from Animal Manure, Pacific Northwest National Laboratory, PNNL-14495, 2003.

[66] D.M.D. Gray, P. Suto, C. Peck, Anaerobic Digestion of Food Waste, EPA-R9WST-06-004 (2008)

[67] N. Curry, P. Pillay, Renew. Energy 41 (2012) 200.

[68] R. Zhang, H.M. El-Mashad, K. Hartman, F. Wang, G. Liu, C. Choate, P. Gamble, Bioresour. Technol. 98 (2007) 929

[69] A. Almodares, M.R. Hadi, Afric. J. Agric. Res. 4 (2009) 772.

[70] A. Boussaid, J. Robinson, Y.J. Cai, D.J. Gregg, J.R. Saddler, Biotechnol. Bioeng. 64 (1999) 284

[71] M. Laser, D. Schulman, S.G. Allen, J. Lichwa, M.J. Antal Jr., L.R. Lynd, A comparison of liquid hot water and steam pretreatments of sugar cane bagasse fo bioconversion to ethanol, Bioresource Technol. 81 (2002) 33.

[72] G.P. van Walsum, S.G. Allen, M.J. Spencer, M.S. Laser, M.J. Antal Jr., L.R. Lynd Conversion of lignocellulosics pretreated with hot compressed liquid water to ethanol, in: Seventeenth Symposium on Biotechnology for Fuels and Chemicals: Presented as Volumes 57 and 58 of Appl. Biochem. Biotechnol., 1996, p. 157.

[73] X. Zhao, L. Zhang, D. Liu, Bioresource Technol. 99 (2007) 3729.

[74] Z. Xu, Q. Wang, Z. Jiang, X.-X. Yang, Y. Ji, Biomass Bioenerg. 31 (2007) 162

[75] M.J. Taherzadeh, K. Karimi, BioResources 2 (2007) 472.

[76] M.J. Taherzadeh, K. Karimi, BioResources 2 (2007) 707.

[77] S. Phillips, A. Aden, J. Jechura, D. Dayton, Thermochemical ethanol via indirect gasification and mixed alcohol synthesis of lignocellulosic biomass, 2007 (NREL/TP-510-41168).

[78] P.W. Gallagher, H. Shapouri, USDA's 2002 ethanol cost-of-production survey, Department of Agriculture, US, 2005

[79] Minnesota Technical Assistance Program, MTAP, Ethanol benchmarking and best practices. The production process and potential for improvement, 2010, Available from: http://mntap.umn.edu/MnTAP\%20Ethanol\%20Report.pdf (accessed 02.07.14).

[80] S. Mueller, Renewable Fuels Association, Report National Dry Mill Corn Ethanol Survey, 2008, Available from: http://www.ethanol.org/pdf/ contentmgmt/Ethanol_production_efficiency_U_of_IL_spring_2010.pdf (accessed 02.07.14)

[81] I.E. Grossmann, M. Martín, Chin. J. Chem. Eng. 18 (2010) 914.

[82] M. Wu, Assessing impact of biofuel production on regional water resource use and availability, Department of Energy Webinar Office of Biomass Program, EERE, DOE, 2012, Available from: http://www1.eere.energy.gov/ bioenergy/pdfs/wu_webinar.pdf (accessed 02.07.14).

[83] Available from: http://news.thomasnet.com/companystory/Bateman-LitwinBuys-Delta-T-Gains-Ethanol-Technology-Edge-525435 (accessed 02.07.14).

[84] S.B. Jones, C. Valkenburg, C.W. Walton, D.C. Elliott, J.E. Holladay, D.J. Stevens C. Kinchin, S. Czernik, Production of gasoline and diesel from biomass via fast pyrolysis, hydrotreating and hydrocracking: a design case, US Dept. of Energy,
PNNL-18284, 2009, Available from: http://www.pnl.gov/main/publications external/technical_reports/pnnl-18284.pdf (accessed 03.07.14).

[85] D. Humbird, R. Davis, L. Tao, C. Kinchin, D. Hsu, A. Aden, P. Schoen, J. Lukas, B. Olthof, M. Worley, D. Sexton, D. Dudgeon, Process design and economic for biochemical conversion of lignocellulosic biomass to ethanol, dilute-acid pretreatment and enzymatic hydrolysis of Corn Stover, U.S. Dept. of Energy, NREL/TP-5100-47764, 2011, Available from: http://www.nrel.gov/docs/ fy110sti/47764.pdf (accessed July 03.07.14).

[86] S. Licht, Fermentation for biofuels and bio-based chemicals, in: C.C. Todaro H.C. Vogel (Eds.), Fermentation and Biochemical Engineering Handbook, 3rd ed., Elsevier, Amsterdam, 2014, pp. 59-82.

[87] T. Werpy, G. Petersen, J.E. Holladay, A. Aden, J.J. Bozell, J.F. White, D. Johnson, A. Manheim, U.S. Department of Energy, Top Value Added Chemicals from Biomass, DOE/CO-102004, 1992, Available from: http://www1.eere. energy.gov/biomass/pdfs/35523.pdf (accessed 16.07.14).

[88] P. Gallezot, Chem. Soc. Rev. 41 (2012) 1538-1558.

[89] R.J. van Putten, J.C. van der Waal, E. de Jong, C.B. Rasrendra, H.J. Heeres, J.G. de Vries, Chem. Rev. 133 (2013) 1499-1597.

[90] M. Rose, R. Palkovits, ChemSusChem 5 (2012) 167-176.

[91] B.O. de Beeck, J. Geboers, S. Van de Vyver, J. Van Lishout, J. Snelders, W.J.J. Huijgen, C.M. Courtin, P.A. Jacobs, B.F. Sels, ChemSusChem 6 (2013) 199-208.

[92] A.R. Fenouillot, G. Colomines, R. Saint-Loup, J.-P. Pascault, Prog. Polym. Sci. 35 (2010) 578-622.

[93] X. Tong, Y. Ma, Y. Li, Appl. Catal. A: Gen. 385 (2010) 1-13.

94] J.J. Bozell, L. Moens, D.C. Elliot, Y. Wang, G.G. Neuenscwander, S.W. Fitzpatrik, R.J. Biliski, J.L. Jarnefeld, Resour. Conserv. Recycl. 28 (2000) 227.

[95] B. Girisuta, L.P.B.M. Janssen, H.J. Heeres, Chem. Eng. Res. Des. 84 (2006) 339.

[96] R.H. Leonard, Ind. Eng. Chem. 48 (1956) 1331

[97] G.J. Mulder, J. Prakt. Chem. 21 (1840) 203.

[98] Á. Szabolcs, M. Molnár, G. Dibó, L.T. Mika, Green. Chem. 15 (2013) 439

[99] B. Girisuta, Levulinic Acid from Lignocellulosic Biomass (Ph.D. dissertation), University of Groningen, 2007.

[100] H. Mehdi, V. Fábos, R. Tuba, A. Bodor, L.T. Mika, I.T. Horváth, Top. Catal. 48 (2008) 49.

[101] A.M.R. Galletti, C. Antonetti, V. De Luise, D. Licursi, N.N. Di Nasso, BioResources 7 (2012) 1824

[102] G. Novodárszki, N. Rétfalvi, G. Dibó, P. Mizsey, E. Cséfalvay, L.T. Mika, RSC Adv 4 (2014) 2081.

[103] B. Girisutaa, B. Danona, R. Manurungc, L.P.B.M. Janssena, H.J. Heeres, Bioresources Technol. 99 (2008) 8367.

[104] C.P. Sassenrath, W.L. Shilling, Patent Appl. US 3258481 (1966)

[105] W.W. Moyer, Patent Appl. US 2270328 (1942).

[106] R.W. Thomas, H.A. Schuette, J. Am. Chem. Soc. 53 (1931) 2324-2328.

[107] L.J. Carlson, Patent Appl. US 3065263 (1962)

[108] I.T. Horváth, H. Mehdi, V. Fábos, L. Boda, L.T. Mika, Green Chem. 10 (2008) 238.

[109] J.Q. Bond, J.A. Dumesic, D.M. Alonso, D. Wang, R.M. West, Science 327 (2010) 1110

[110] F.M.A. Geilen, B. Engendahl, A. Harwardt, W. Marquardt, J. Klankermayer, W. Leitner, Angew. Chem. Int. Ed. 49 (2010) 5510-5514.

[111] D. Fegyverneki, L. Orha, G. Láng, I.T. Horváth, Tetrahedron 66 (2010) 1078-1081.

[112] A. Strádi, M. Molnár, M. Óvári, G. Dibó, F.U. Richter, L.T. Mika, Green Chem. 15 (2013) 1857-1862.

[113] P.K. Wong, C. Li, L. Stubbs, Patent Appl. WO 2012/134397A1 (2012).

[114] M. Chalid, H.J. Heeres, A.A. Broekhuis, J. Appl. Polym. Sci. 123 (2011) 3556-3564.

[115] J.-P. Lange, R. Price, P.M. Ayoub, J. Louis, L. Petrus, L. Clarke, H. Gosselink, Angew. Chem. Int. Ed. Engl. 49 (2010) 4479-4483.

[116] L. Qui, IT. Horváth, ACS Catal. 2 (2012) 2247-2249.

[117] I.T. Horváth, Green Chem. 10 (2008) 1024-1028.

[118] F. Joó, M.T. Beck, React. Kinet. Catal. Lett. 2 (1975) 257.

[119] F. Joó, Z. Tóth, M.T. Beck, Inorg. Chim. Acta 25 (1977) L61.

[120] M. Chalid, A.A. Broekhius, H.J. Heeres, J. Mol. Catal. A: Chem. 341 (2011) 14

[121] C. Delhomme, L.-A. Schaper, M. Zhang-Presse, G. Raudaschl-Sieber, D. Weuster-Botz, F.E. Kühn, J. Organomet. Chem. 724 (2013) 297-299.

[122] J. Deng, Y. Wang T. Pan, Q. Xu, Q.-X. Guo, Y. Fu, ChemSusChem 6 (2013) 1163.

[123] J.M. Tukacs, D. Király, A. Strádi, G. Novodárszki, Z. Eke, G. Dibó, T. Kégl, L.T. Mika, Green Chem. 4 (2012) 2057

[124] J.M. Tukacs, G. Dibó, L.T. Mika, Catal. Sci. Technol. 4 (2014) 2908

[125] V. Fábos, L.T. Mika, I.T. Horváth, Organometallics 33 (2014) 181-187.

[126] R. Wright, R. Palkovits, ChemSusChem 5 (2012) 1657-1667.

[127] M.G. Al-Shaal, W.R.H. Wright, R. Palkovits, Green Chem. 14(2012)1260-1263.

[128] J.M. Tukacs, R.V. Jones, F. Darvas, G. Dibó, G. Lezsák, L.T. Mika, RSC Adv. 3 (2013) 16283

[129] J.G. Zeikus, M.K. Jain, P. Elankovan, Apll. Microbiol. Biotechnol. 51 (1999) $545-552$.

[130] L. Yu, X.-L. Du, J. Yuan, Y.-M. Liu, Y. Cao, H.-Y. He, K.-N. Fan, ChemSusChem 6 (2013) 42-46

[131] K. Stamatelatou, G. Antonopoulou, G. Lyberatos, Lyberatos Production of Biogas Via Anaerobic Digestion in Handbook of Biofuels Production, Woodhead Publishing Series, Amsterdam, 2011, pp. 266-304.

[132] M. Crocker, Thermochemical Conversion of Biomass to Liquid Fuels and Chemicals, The Royal Society of Chemistry, Cambridge, 2010.

[133] G. Huber, S. Iborra, A. Corma, Chem. Rev. 106 (2006) 4044-4098. 
[134] W. Lan, G. Chen, X. Zhu, B. Wang, J. Xu, Energy Inst. (2014), http://dx.doi.org/ 10.1016/j.joei.2014.05.003 (in press).

[135] A. Payen, Compt. Rend. 8 (1839) 51-53.

[136] D.N.-S. Hon, Cellulose 1 (1994) 1-25.

[137] R. Rinaldi, F. Schüth, ChemSusChem 2 (2007) 1096-1107.

[138] B.F.M. Kuster, Starch/Staerke 42 (1990) 314-321.

[139] G.R. Akien, L. Qi, I.T. Horváth, Chem. Commun. 48 (2012) 5850-5852.

[140] T.S. Hansen, J.M. Woodley, A. Riisager, Carbohydrate Res. 344 (2009) 2568-2572.

[141] H. Zhao, J.E. Holladay, H. Brown, Z.C. Zhang, Science 316 (2007) 1597-1600.

[142] T. Ståhlberg, S. Rodriguez-Rodriguez, P. Fristup, A. Riisager, Chem. Eur. J. 17 (2011) 1456-1465.

[143] J. Horvat, B. Klaić, B. Metelko, V. Śunjić, Tetrahedron Lett. 26 (1985) 2111-2114

[144] J. Zhang, E. Weitz, ACS Catal. 2 (2012) 1211-1218

[145] P.R. Rege, L.H. Block, Carbohydr. Res. 321 (1999) 235-245.

[146] A. Tolaimate, J. Debrieres, M. Rhazi, A. Alagui, Polymer 44 (2006) 7939-7952.

[147] C.K.S. Pillai, W. Paul, C.P. Sharna, Progr. Polit. Sci. (2009) 641-678.

[148] K.W. Omari, J.E. Besaw, F.M. Kerton, Green Chem. 14 (2012) 1480-1487.

[149] F.E. Wolter, K. Schneider, B.P. Davies, E.R. Socher, G. Nicholson, O. Seitz, R.D. Süssmuth, Org. Lett. 11 (2009) 2804-2807.

[150] M.W. Drover, K.W. Omari, J.N. Murphy, F.M. Kerton, RSC Adv. 2 (2012) 4642-4644.

[151] K.W. Omari, L. Dodot, F.M. Kerton, ChemSusChem 5 (2012) 1767-1772.

[152] H.E. Hoydonckx, W.M. Van Rhijn, W. Van Rhijn, D.E. De Vos, P.A. Jacobs, Furfural and Derivatives in Ullmann's Encyclopedia of Industrial Chemistry, Wiley-VCH, Hoboken, NJ, 2007, http://dx.doi.org/10.1002/14356007. a12_119.pub2.

[153] K.J.Zeitsch, Sugar Series, vol.13, 1st ed., Elsevier, Amsterdam, 2000, pp. 34-69.

[154] J.C. Serrano-Ruiz, J.M. Campleo, M. Francavilla, A.A. Romero, R. Luque, C. Menéndez-Vázquez, A.B. García, E.J. García-Suarez, Catal. Sci. Technol. 2 (2012) 1828-1832.

[155] M. Möller, U. Schröder, RSC Adv. 3 (2013) 22253-22260.

[156] E. Arceo, J.A. Ellman, R.G. Bergman, J. Am. Chem. Soc. 132 (2010) 11408-11409.

[157] S.C.A. Souza, A.C. Fernandes, Tetrahedron Lett. 52 (2011) 6960-6962.

[158] S. Stanowski, K.M. Nicholas, R.S. Srivastava, Organometallics 31 (2012) 515-518.

[159] M. Shiramizu, F.D. Toste, Angew. Chem. Int. Ed. 51 (2012) 8082-8086.

[160] E.-S. Koh, T.-H. Lee, D.-Y. Lee, H.-J. Kim, Y.-W. Ryu, J.-H. Seo, Biotechnol Lett. 25 (2003) 2103-2105.

[161] R.N. Monrad, R. Madsen, J. Org. Chem. 72 (2007) 9782-9785.

[162] I.T. Clark, Ind. Eng. Chem. 50 (1958) 1125.

[163] D.K. Sohounloue, C. Montassier, J. Barbier, React. Kinet. Catal. Lett. 22 (1983) 391.
[164] C. Montassier, D. Giraud, J. Barbier, Polyol Conversion by Liquid Phase Heterogeneous Catalysis over Metals, Elsevier Science Publishers, Amsterdam, 1988, pp. 165.

[165] N. Yoshinao, T. Keiichi, Catal. Sci. Technol. 1 (2011) 179-190.

[166] E.P. Maris, W.C. Ketchie, M. Murayama, R.J. Davis, J. Catal. 251 (2007) 281294.

[167] C. Montassier, J.C. Ménézo, L.C. Hoang, C. Renaud, J. Barbier, J. Mol. Catal. 70 (1991) 99-110.

[168] M.A. Dasari, P.-P. Kiatsimkul, W.R. Sutterlin, G.J. Suppes, Appl. Catal. A 281 (2005) 225-231.

[169] E.P. Maris, R.J. Davis, J. Catal. 249 (2007) 328-337.

[170] J. Sun, H. Lin, Green Chem. 13 (2011) 135-142.

[171] L. Yu, J. Yuan, Q. Zhang, Y.-M. Liu, H.-Y. He, K.-N. Fan, Y. Cao, ChemSusChem 7 (2014) 743-747.

[172] R. Sheldon, Green Chem. 16 (2014) 950.

[173] T.M. Lammens, J. Potting, J.P.M. Sanders, I.J.M. De Boer, Environ. Sci. Technol. 45 (2011) 8521.

[174] T.M. Lammens, D. De Biase, M.C.R. Franssen, E.L. Scott, J.P.M. Sanders, Green Chem. 11 (2009) 1562.

[175] T.M. Lammens, M.C.R. Franssen, E.L. Scott, J.P.M. Sanders, Green Chem. 12 (2010) 1430.

[176] J. Le Nôtre, E.L. Scott, M.C.R. Franssen, J.P.M. Sanders, Green Chem. 13 (2011) 807.

[177] T.M. Lammens, J. Le Nôtre, M.C.R. Franssen, E.L. Scott, J.P.M. Sanders, ChemSusChem 4 (2011) 785

[178] S. Kind, C. Wittmann, Appl. Microbiol. Biotechnol. 91 (2011) 1287.

[179] J.W. Frost, Patent Appl. WO2005123669 (2005).

[180] A.V. Pukin, C.G. Boeriu, E.L. Scott, J.P.M. Sanders, M.C.R. Franssen, J. Mol. Catal. B: Enzym. 65 (2010) 58.

[181] P.M. Könst, P.M.C.C.D. Turras, M.C.R. Franssen, E.L. Scott, J.P.M. Sanders, Adv Synth. Catal. 352 (2010) 1493-1502.

[182] D.J. Anneken, S. Both, R. Christoph, G. Fieg, U. Steinberg, A. Westfechtel, Fatty Acids in Ullmann's Encyclopedia of Industrial Chemistry, Wiley-VCH, Weinheim, 2012, http://dx.doi.org/10.1002/14356007.a10_245.pub2.

[183] T.A. Patil, D.N. Butala, T.S. Raghunathan, H.S. Shankar, Ind. Eng. Chem. Res. 27 (1988) 727.

[184] J.W. King, R. Holliday, G.R. List, Green Chem. 1 (1999) 261.

[185] E. Twitchell, U.S. Patent Appl US601603 (1898).

[186] G.W. Eisenlohr, U.S. Patent Appl. US2154885 (1939)

[187] L. Lascaray, J. Am. Oil Chem. Soc. 29 (1952) 362.

[188] J.S.S. Pinto, F.M. Lancas, J. Braz. Chem. Soc. 17 (2006) 85.

[189] T. Kocsisová, J. Juhasz, J. Cvengroš, Eur. J. Lipid Sci. Technol. 108 (2006) 652. 